\title{
Intranasal Delivery of Nanoformulations: A Potential Way of Treatment for Neurological Disorders
}

\author{
Salman Ul Islam ${ }^{1}$, Adeeb Shehzad ${ }^{2}$, Muhammad Bilal Ahmed ${ }^{1}$ and Young Sup Lee ${ }^{1, *(D)}$ \\ 1 School of Life Sciences, College of Natural Sciences, Kyungpook National University, Daegu 41566, Korea; \\ dr_ssulman@yahoo.com (S.U.I.); mbilalknu@gmail.com (M.B.A.) \\ 2 Department of Clinical Pharmacy, Institute for Research and Medical Consultations (IRMC), \\ Imam Abdulrahman bin Faisal University, Dammam 31441, Saudi Arabia; asmsiar@iau.edu.sa \\ * Correspondence: yselee@knu.ac.kr; Tel.: +82-53-950-6353; Fax: +82-53-943-2762
}

Academic Editors: Jesús Martínez de la Fuente and Laura Asín

Received: 23 March 2020; Accepted: 17 April 2020; Published: 21 April 2020

\begin{abstract}
Although the global prevalence of neurological disorders such as Parkinson's disease, Alzheimer's disease, glioblastoma, epilepsy, and multiple sclerosis is steadily increasing, effective delivery of drug molecules in therapeutic quantities to the central nervous system (CNS) is still lacking. The blood brain barrier (BBB) is the major obstacle for the entry of drugs into the brain, as it comprises a tight layer of endothelial cells surrounded by astrocyte foot processes that limit drugs' entry. In recent times, intranasal drug delivery has emerged as a reliable method to bypass the BBB and treat neurological diseases. The intranasal route for drug delivery to the brain with both solution and particulate formulations has been demonstrated repeatedly in preclinical models, including in human trials. The key features determining the efficacy of drug delivery via the intranasal route include delivery to the olfactory area of the nares, a longer retention time at the nasal mucosal surface, enhanced penetration of the drugs through the nasal epithelia, and reduced drug metabolism in the nasal cavity. This review describes important neurological disorders, challenges in drug delivery to the disordered CNS, and new nasal delivery techniques designed to overcome these challenges and facilitate more efficient and targeted drug delivery. The potential for treatment possibilities with intranasal transfer of drugs will increase with the development of more effective formulations and delivery devices.
\end{abstract}

Keywords: neurological disorders; Parkinson's disease; Alzheimer's disease; glioblastoma; epilepsy; multiple sclerosis; nose-to-brain; blood brain barrier; nanoformulations

\section{Introduction}

Improving the prognoses of diseases of the central nervous system (CNS) such as Parkinson's diseases (PD), Alzheimer's diseases (AD), and brain tumors has always been a greater challenge than those of diseases affecting other organs [1-3]. Reportedly, $>90 \%$ of newly proposed CNS drugs have not been approved by the US Food and Drug Administration (FDA) [4]. The presence of the complex blood brain barrier (BBB) that limits drug entry to the CNS region is the major obstacle for the development of CNS treatments [5]. Moreover, non-targeted delivery of diagnostic reagents or therapeutic drugs is known to cause significant damage to neurons and glial cells. Therefore, novel delivery platforms bearing the therapeutic drugs for neurological disorders are urgently needed.

In this era, imaging agents or treatments for CNS diseases are highly dependent on nanomedicines, because they play a promising role in CNS drug delivery. It has been shown that nanomedicines can actively and effectively cross the BBB and deeply penetrate the diseased brain tissues. In addition, nanomedicines are also associated with increased strength, stability, surface area, and sensitivity [6,7]. Novel, advanced, and versatile CNS nanomedicines can simultaneously serve diagnostic and 
therapeutic functions; however, a number of optimizations are still required for future widespread clinical applications.

The nasal passage is the brain's only contact with the external environment. Upper posterior segments of the nose are connected with the axons of the 12th cranial nerve. These nerves penetrate the mucosal lining and allow direct contact with the external environment without a peripheral sensory receptor relay. These nerves act as a chemical sensor, detect food scents, and play a role in social behaviors. Additionally, these nerves also offer a potential route for direct access of medication into the CNS [5-7]. Recent studies have shown the potential existence of a functional pathway (sometimes called "nose-to-brain" transport) for drugs to pass into the CNS from structures deep in the nose innervated by cranial nerves $[5,7,8]$.

In this review, we focus on delivery of nanoformulations for the treatment of CNS disorders via the nasal route. This review includes a brief description of neurological diseases and currently developed nanoformulations suited for nose-to-brain delivery. We conclude with a brief discussion on the potential of nanomedicines and the future prospects of intranasal delivery to the CNS for successful clinical trials.

\section{Blood Brain Barrier}

The blood brain barrier (BBB) is made up of a triad of capillary endothelium, pericytes, and the astrocytic foot processes [9]. Specialized endothelial cells of the BBB lack fenestration, possess extensive tight junctions that severely restrict cell permeability, and have few pinocytic vesicles to minimize uptake of extracellular substances (Figure 1) [10]. Therefore, the transport of drugs is hindered and only few drugs can reach brain tissue. This is most likely why therapeutic agents that show in vitro efficacy fail to show in vivo activity. Drug delivery to the brain is always a great challenge unless the existing therapeutics have been customized [11]. It has been shown that small lipophilic molecules with molecular weights less than 400 Da can easily diffuse through the BBB, while large or hydrophilic molecules require special assistance like gated channels, proteins and/or the ligand-specific receptors, and ATP-mediated energy [12]. To maximize drug delivery into the brain, two basic approaches have been applied: a molecular approach and a polymeric carrier approach. In the molecular approach, drugs are delivered to the brain cells in the native form that are then activated by the target cell-specific enzymes. However, the limited availability of such drugs and their corresponding metabolic pathways has restricted the use of this approach. The polymeric carrier approach employs polymeric nanoparticles as the vehicles, which not only enhances the physiochemical stability of the therapeutic substances but also facilitates the administration through intravenous and intrathecal routes or as cerebral device implants [9]. 

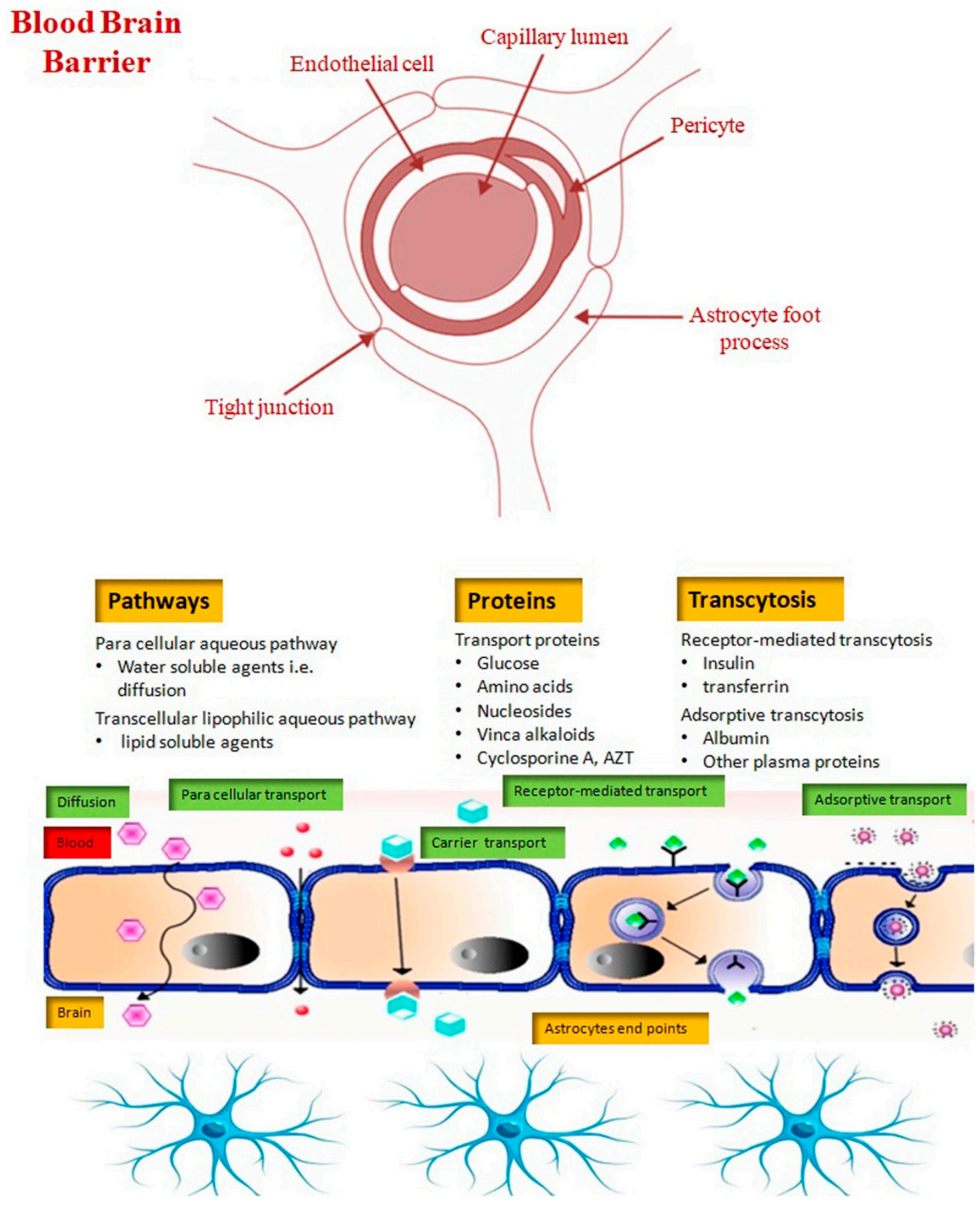

Figure 1. Schematic demonstrating various transport systems that shuttle molecules across the BBB. Very small amount of water-soluble compounds cross through the tight junctions (paracellular), whereas lipid-soluble agents traverse via the transcellular lipophilic pathway. Selective transport systems exist for glucose, amino acids, nucleosides, and other substances, in addition to specific receptor-mediated endocytosis for certain proteins such as insulin and transferrin. (AZT = azathioprine).

\section{List of CNS Diseases}

\subsection{Parkinson's Disease (PD)}

PD, occurring primarily in the substantia nigra, is the second-most common neurodegenerative disease, leading to the development of bradykinesia and tremors of cardinal motor functions 
(Figure 2) [3]. PD models specifically show a decrease in dopamine transporters, which are responsible for dopamine uptake by dopaminergic neurons and progression of neuronal communications. Reduced dopamine delivery during PD results in significant loss of neuronal functions [13]. Another hallmark of PD is the accumulation of $\alpha$-synuclein in the Lewy bodies. However, the underlying mechanisms for PD-induced dementia are poorly understood [14]. The progression of PD can be delayed by levodopa-the precursor of dopamine-or a levodopa agonist [15,16]. However, it has been shown that untargeted delivery of levodopa can attack the peripheral nervous system leading to dyskinesia and adverse cardiovascular effects [17]. Therefore, it is advisable to carefully deliver neurotransmitters for PD treatment across the BBB by using a suitable delivery system, which does not allow penetration into other peripheral vessels.
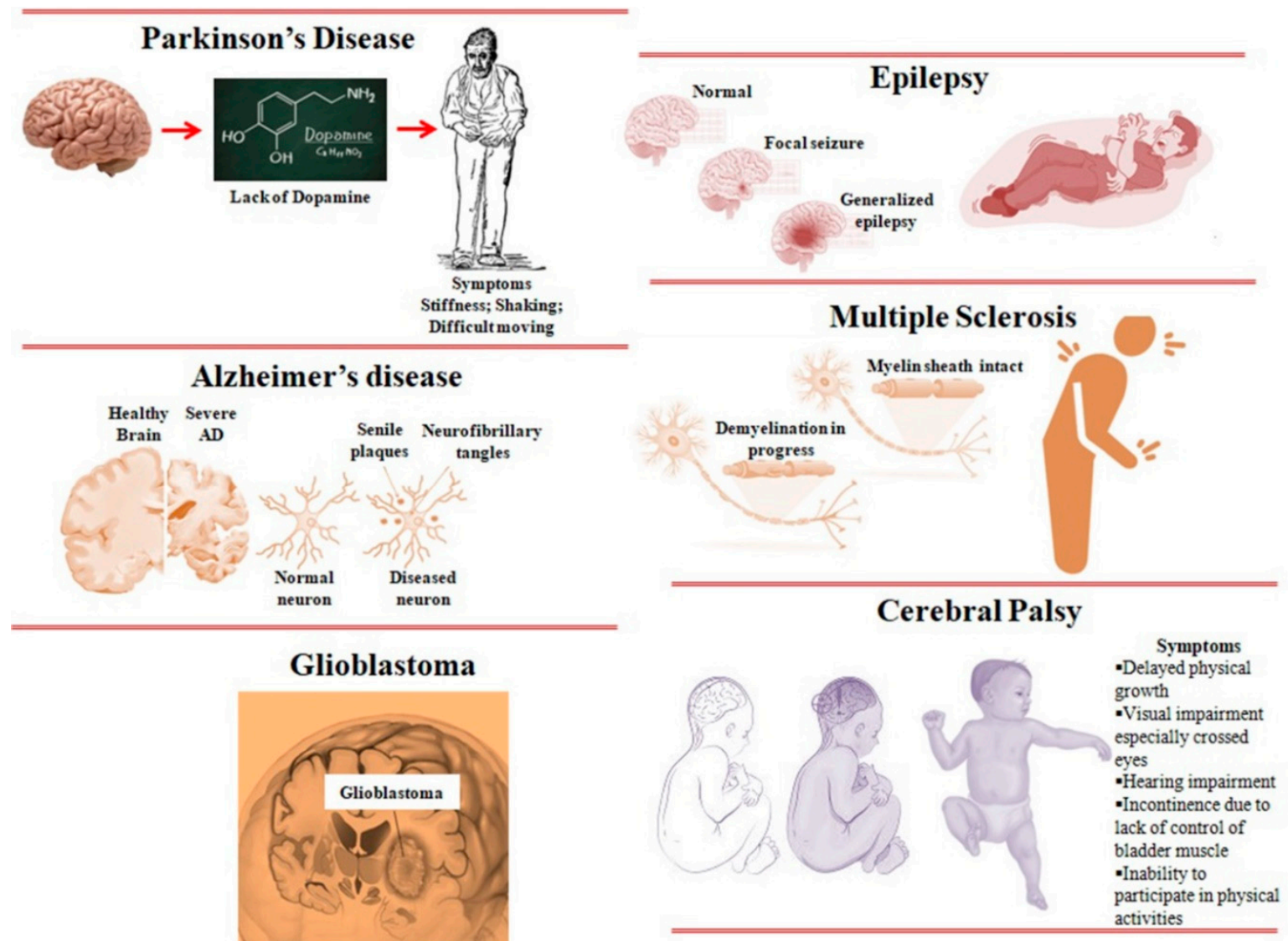

Figure 2. Important neurological disorders.

\subsection{Alzheimer's Disease (AD)}

$\mathrm{AD}$ is an irreversible and progressive neurodegenerative brain disorder that affects patients' memory, cognition, language skills, and behavior [18]. At present, there is no known cure for AD given the lack of understanding of its molecular and intercellular mechanisms. However, treatments are available to improve the symptoms and on-going research is aimed at finding a cure. Accumulation of amyloid-beta $(\mathrm{A} \beta)$ peptides, neurofibrillary tangle formation of phosphoric tau proteins, and detrimental neuroinflammation are the signature features of AD progression [19]. The major biochemical markers for diagnostic purposes include $A \beta$ plaques around the affected brains and presence of soluble $A \beta$ and tau proteins in the cerebrospinal fluids, which are targeted. Inhibition of $A \beta$ plaque/tau tangle formation and neutralization of their aggregations around neurons is the main focus of advanced therapeutic strategies [20-22]. The current clinically approved drugs can only relieve symptoms and delay AD progression by promoting interactions between neurons in $\mathrm{AD}$ 
brains through neurotransmitters [23]. Therefore, the discovery of novel AD markers and development of advanced and potent nanomedicines to target these AD markers is crucial for effective treatment and cure.

\subsection{Glioblastoma (GBM)}

GBM is the most common high-grade primary brain tumor in adults. It is also known to occur in children, albeit rarely [24]. GBM is the deadliest form of primary brain tumor, and originates from glial cells. It has been shown that even after aggressive multimodal therapy including chemotherapy, radiation, surgery, and their combined treatments, the median survival rate is 14 months, which emphasizes the urgent need for developing an effective strategy to eradicate brain tumors [1,25]. The discovery of highly expressed novel markers of brain tumors and the application of these markers in several nanoformulations functionalized with targeting ligands has notably improved the treatment and elimination of brain tumors [8,26-31]. Another recent and emerging anticancer approach that led to an explosion of clinical trials is immunotherapy, defined by targeting immune checkpoint receptors expressed on adaptive immune cells to improve immune surveillance [32]. However, with immunotherapy, the targeting efficiency is reduced resulting in incomplete elimination of tumors, and recurrence occurs because of the intratumor heterogeneity among individual patients. Therefore, the development of advanced and potent nanomedicines equipped with multimodal treatment systems is urgently needed for total removal of cancers.

\subsection{Epilepsy}

Epilepsy is a disorder of the CNS characterized by periodic loss of consciousness with or without epileptic seizures associated with abnormal electrical activity in the brain $[33,34]$. Epileptic seizures can result from almost any insult that perturbs brain function: for example, traumatic brain injury or stroke, infectious diseases such as neurocysticercosis, autoimmune diseases, and genetic mutations [35]. Currently, more than 500 genes associated with epilepsy have been identified. However, in most cases, epilepsy is idiopathic [33]. Epilepsy is related to physical risks and psychological and socioeconomic consequences which impair patients' quality of life. An epileptic seizure is caused by abnormal excessive or synchronous neuronal activity in the brain. The epileptic seizure is a transient behavioral change, associated with symptoms like stiffening, jerking, loss of awareness, a smell of burnt rubber, or déjà $v u$, and a sensation that rises from the abdomen to the chest. Epileptic-seizure onset can be generalized (neuronal abnormal activity in a widespread distribution over both hemispheres), focal (neuronal abnormal activity in one or more localized brain regions or hemisphere), or of unknown origin (when it is not known whether the onset is focal or generalized) [36]. Onset of epilepsy is determined when there is $>80 \%$ confidence based on the electroencephalography, clinical features, and neuroimaging findings [37].

\subsection{Multiple Sclerosis}

Multiple sclerosis (MS) is the well-known chronic demyelinating disorder of the CNS in young adults. MS is a heterogeneous, multifactorial, immune-mediated disorder, and is influenced by both genetic and environmental factors [38-40]. The initial stages of MS are characterized by reversible episodes of neurological dysfunction lasting several days or weeks. Irreversible clinical and cognitive deficits develop over time [39]. Some patients have a progressive disease course from the onset. Formation of demyelinating lesions in the brain and spinal cord is the pathological hallmark of MS, which can be associated with neuro-axonal damage [41]. During MS, infiltration of immune cells such as T cells, B cells, and myeloid cells into the CNS parenchyma causes focal lesions with associated injury [42]. MS creates a substantial burden on society with respect to high cost of available treatments, and poorer employment prospects. 


\subsection{Cerebral Palsy (CP)}

$\mathrm{CP}$ is a common pediatric disorder occurring in about 2-2.5 per 1000 live births [43]. In the traditional sense, $\mathrm{CP}$ is not a disease entity, rather a clinical manifestation seen in children who share antenatal, perinatal, or early postnatal period-acquired features of a non-progressive brain injury or lesion. It has been noted that the clinical manifestations of $\mathrm{CP}$ vary greatly in the type of movement disorder, degree of functional ability and limitation, and the affected areas of the body [44]. Currently, there is no cure for $\mathrm{CP}$, but there are advancements in areas of both prevention and treatment of brain injury. For instance, magnesium sulfate administration during premature labor and cooling of high-risk infants has been shown to reduce the rate and severity of CP [45]. Currently, most CP research and management strategies are focused on the needs of children, although the disorder affects individuals throughout their lifetime. Clinical researchers concerned with the management of children with $\mathrm{CP}$ are struggling to maximize function and participation in activities and minimize the factors that worsen the condition, such as feeding challenges, epilepsy, scoliosis, and hip dislocation [44]. Noteworthy management strategies comprise improving neurological function during early development, enhancing motor function through rehabilitation technologies, overcoming weakness and hypertonia, and preventing secondary musculoskeletal problems [44]. However, it is particularly challenging to meet the needs of people with $\mathrm{CP}$ in resource-poor settings.

\section{Nanoformulations for Brain Disorders}

\subsection{Polymeric Nanosuspensions}

Polymeric nanosuspensions are typical drug-loaded nanoformulations stabilized by using either lipid mixtures or non-ionic surfactants. Polymeric nanosuspensions have numerous advantages including enhanced drug loading, ease of fabrication, improved pharmacokinetics, and the possibility of surface modifications (Figure 3) [46]. However, the preparation of polymeric nanosuspensions takes very long and are not considered the formulations of choice for chronic disease therapy owing to their unstable shelf life [47].

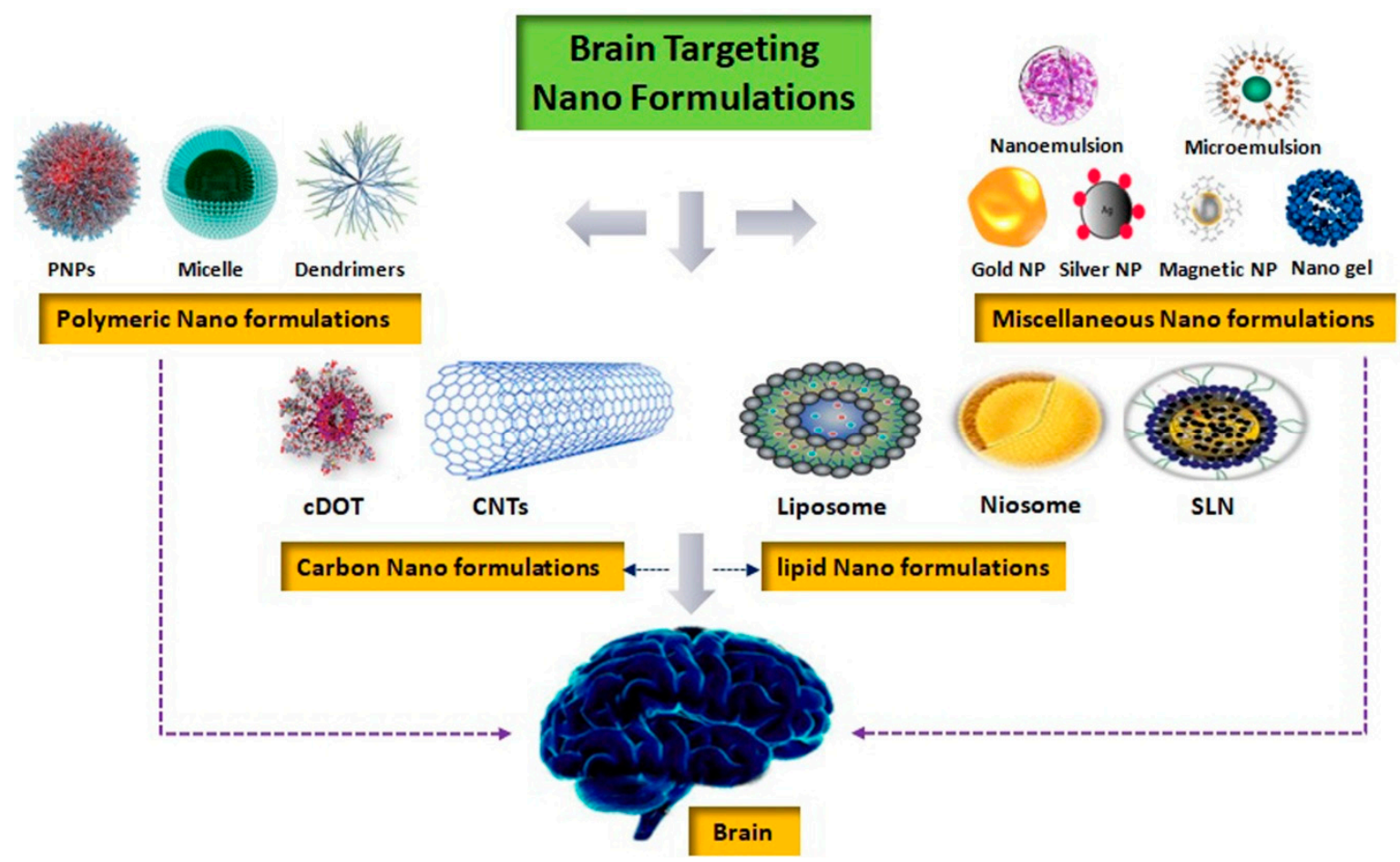

Figure 3. Various important brain targeting nanoformulations. 


\subsection{Polymeric Nanogels}

Polymeric nanogels are the cross-linked hydrophilic or amphiphilic polymers that are fabricated by emulsification followed by solvent evaporation $[48,49]$. The nanogel formulation is based on the principle of ionic and non-ionic polymers coalescing and forming cross-linked networks [50]. Polymeric nanogels are considered to provide more protection to the entrapped drugs during the transport process than other nanoformulations [49]. Polymeric nanogels have been mainly used to deliver DNA, siRNA, and oligonucleotides with an encapsulation efficiency of $40 \%-60 \%$ [51]. Nanogels have also been shown to deliver oligonucleotides specifically to the brain with more efficiency than to the spleen and liver [52].

\subsection{Polymeric Nanoliposomes}

Polymeric nanoliposomes represent a vesicular structure, containing an internal aqueous compartment and an outside covering of single or multi-lamellar lipid layers. This structural design of nanoliposomes facilitates enhanced stability and drug encapsulation along with evasion from the reticuloendothelial system [53]. Although the stability of nanoliposomes for brain disorders is still debatable, a report has shown that curcumin nanoliposomes were specifically active against amyloid aggregates [54].

\subsection{Niosomes}

Niosomes are nanoscale vesicles, having a stable bilayer structure, and are mainly composed of non-ionic surfactants and cholesterol. Niosomes are highly biocompatible and biodegradable [55]. They exhibit high chemical stability, long shelf life, low toxicity, and inexpensive manufacturing cost. Niosomes have the ability to entrap lipophilic or hydrophilic drugs and are able to deliver the drug molecules at target site in a sustained and/or controlled manner [56,57]. Niosomes have been reported to modify drugs organ distribution and metabolic stability [58]. It has been shown that surface modification of the niosomes promotes the target specificity for the cancer drug delivery system. For instance, modification of temozolomide-loaded niosomes with chlorotoxin, a target-specific peptide, significantly enhanced the gliomas targeting efficiency of the temozolomide [59]. A study reported that surface modified niosomes containing olanzapine (an atypical antipsychotic drug) showed a 3 -fold increase in olanzapine concentration in the brain compared to the intranasal solution of the drug [60]. In an attempt to provide a novel pharmacological approach to ameliorate PD induced by subchronic MPTP administration in C57BL-6J mice, a group of researchers developed a non-invasive intranasal delivery system, composed of chitosan coated niosomes with entrapped pentamidine (inPentasomes). The study demonstrated that inPentasomes, because of their capability to inhibit glial-derived S100B activity, rescued the dopaminergic neuronal loss and reduced the severity of neuroinflammation occurred in the nigrostriatal pathway, which subsequently led to a significant improvement in parkinsonian motor dysfunctions [61]. Another similar investigation reported the preparation of drug free and pentamidine loaded chitosan glutamate coated niosomes for intranasal drug delivery using thin film hydration method. In this study, particular attention was given to observe the interactions of both drug free and pentamidine loaded niosomes with the mucin. It was demonstrated that niosomal formulation effectively delivered pentamidine or other possible drugs to the brain via nasal administration [62]. A study reported the formulation of buspirone hydrochloride (an anxiolytic agent and serotonin receptor agonist) niosomal in situ nasal gel in order to overcome the problems of short half-life (2-3 h) and low oral bioavailability (4\%) of buspirone hydrochloride. It was shown that the application of niosomes proved the potential for intranasal delivery of the buspirone hydrochloride over the conventional gel formulations [63]. 


\subsection{Nanospheres and Nanocapsules}

Nanospheres are the solid core polymeric matrices fabricated by the micro-emulsion polymerization technique, whereas nanocapsules exhibit vesicular systems where a thin nontoxic polymer encapsulates the oil-filled drug compartment [64,65]. Both nanospheres and nanocapsules offer the advantages of improved drug stability, easy surface modification, and evasion of systemic degradation. However, they also have certain limitations such as complicated purification and storage as well as improper drug-release patterns [66,67]. Indomethacin-loaded nanocapsules have been shown to protect hippocampal cultures against in vitro inflammation [68].

\subsection{Polymeric Nanomicelles}

Polymeric nanomicelles contain a hydrophobic core surrounded by the shell constituting hydrophilic polymer blocks [69]. The shell stabilizes and disguises polymeric nanomicelles from cellular interactions, while the core can encapsulate about $30 \%$ of hydrophobic drugs [70,71]. It is estimated that polymeric nanomicelles could be effective for both in vitro and in vivo delivery of DNA molecules, although no reports exist yet on the nanomicelle-mediated CNS drug delivery. It has been shown in vitro that PEGylated phospholipid nanomicelles revoked amyloid-induced toxicity [72]. However, polymeric nanomicelles are not feasible for encapsulating hydrophilic drugs. Additionally, they have a shorter shelf life [73].

\subsection{Metal Nanoparticles}

Metal nanoparticles have been the focus of recent research given their potential applications in the fields of biomedical engineering and sciences [74]. Metal nanoparticles can be synthesized with the inclusion of several structural and surface modifications, which opens new horizons for their application in the fields of magnetic separation, targeted gene and drug delivery, and particularly, in diagnostic imaging [75-77]. Multiple modern and advanced imaging techniques like SERS, CT, MRI, PET, and ultrasound require a contrast agent for effective functioning. This requirement of a contrast agent provided the basis for the formulation of nano-sized gold, silver, and magnetic iron oxide $\left(\mathrm{Fe}_{3} \mathrm{O}_{4}\right)$ nanoparticles [78-80].

\subsection{Gold Nanoparticles}

Gold nanoparticles (AuNPs) are widely used as nanomaterials for drug delivery and imaging [81]. Studies have shown that AuNPs exhibit low specificity because of absence of a selective moiety that can discriminate between targeted and non-targeted cells [82]. For delivering the therapeutic substances to targeted cells or tissues, researchers have been combined the AuNPs with cell-targeting ligands. The surface area of AuNPs provides a platform for conjugating multiple proteins, peptides, aptamers, and antibodies [83]. However, these conjugating methodologies are very complex as well as system-specific, which limits cross-system application. Additionally, several substances are not appropriate for clinical application because of potential toxicity resulting from the use of surfactants such as cetyl trimethylammonium bromide [84]. AuNPs for neuronal uptake can be utilized through two main routes: crossing the BBB and through the olfactory nerves. During an investigation, researchers successfully employed nose-to-brain direct transport pathway to deliver theranostic polyfunctional gold-iron oxide nanoparticles, surface loaded with miR-100 and antimiR-21, to GBMs in mice [85]. A study reported the formulation of resveratrol-loaded transferosomes and nanoemulsions labelled with gold nanoparticles for targeting the brain through intranasal route. The effectiveness of brain targeting of these two nanoformulations were achieved via testing the memory recovery of Wistar albino rats through a water maze test and bioaccumulation investigations using computed tomography and histopathological examination. It was observed that transferosomes significantly promoted behavioral acquisition and spatial memory function in the amnesic rats compared with both 
the nanoemulsion formulation and the pure drug [86]. It has been reported that AuNPs may lead to astrogliosis, increased seizure activity, and judgement impairments after crossing the BBB [87].

\subsection{Silver Nanoparticles}

Silver nanoparticles (AgNPs) have been shown to induce cytotoxicity in human skin, lungs, and fibroblast cells $[88,89]$. In relation to the CNS, it has been shown that AgNPs, following inhalation and ingestions, cross the BBB and accumulate in the brain [90-92]. Patchin et al. found rapid translocation of $20 \mathrm{~nm}$ AgNPs into the olfactory bulb, with slower and less effective transport of $110 \mathrm{~nm}$ silver particles after a 6-h exposure [93]. A study reported very little AgNP absorption (measured as total silver) into the blood after intranasal administration and significantly higher blood concentrations after AgNO3 delivery, and demonstrated that silver found in the blood was due to silver ion release from AgNPs [94]. AgNPs have also been shown to induce cytotoxicity in neurons in vitro [95]. However, the exact mechanisms of AgNPs causing neurodegeneration are poorly understood, and this topic needs to be more thoroughly investigated. In contrast to the above facts, a study reported that AgNPs showed remarkable anti-inflammatory effects, reduced LPS-induced ROS, nitric oxide and TNF $\alpha$ production, which resulted into decreased microglial toxicity towards dopaminergic neurons [96]. Therefore, further investigations are required to take decisions about how to design future classes of safe AgNPs.

\subsection{Magnetic Nanoparticles}

Magnetic nanoparticles (MNPs) are actually the nanoparticles which exhibit magnetic properties. These are capable of producing temporary pores in the cell membranes, as is the case in the BBB endothelium, which enhance drugs targeting and delivery; the phenomenon is termed as magnetoporation [97]. MNPs have been utilized in multiple biomedical applications including magnetic hyperthermia and heating, magnetic vectors and magnetic contrast agents [98-100]. In an attempt to establish a promising treatment for PD, researchers developed a nanocarrier composed of $\mathrm{Fe} 3 \mathrm{O} 4$ nanoparticles coated with oleic acid molecules and absorbed short hairpin RNA. It was shown that these superparamagnetic nanoparticles reduced the expression of $\alpha$-synuclein, suppressed its toxic effects on the cells, and blocked $\alpha$-synuclein-induced cell death [101]. Another study reported the successful delivery of mesenchymal stem cells (MSCs) and improved neurobehavioral assessment when MSCs were incubated with micrometer-sized iron particles and finally administrated them in a PD mouse model by the way of the intranasal route [102]. It has been recently demonstrated that dextran-coated iron oxide nanoparticles enhanced the therapeutic efficacy of human MSCs in a mouse model of PD by decreasing the loss of dopaminergic neurons and increasing the differentiation of human MSCs to dopaminergic neurons [103].

\subsection{Dendrimers}

Dendrimers have a characteristic architecture consisting of molecular hooks and are a novel class of highly branched nanoparticles that can target specific cells [104]. Two basic structures for dendrimers have been demonstrated of which one represents a central core with radiating polymer branches, and the other type only shows multiple branches without the core [105]. Because of the unique branching structure of dendrimers, surface modifications through either adsorption or covalent conjugation become very easy, which also enhances the potential of dendrimers to carry various drugs [106,107]. Polyamidoamine dendrimers have been shown to be used to fabricate tunable drug delivery systems with the potential to target intracellular components both in vitro and in vivo [108]. Additionally, dendrimers can also be used as scaffolds for delivering therapeutic and diagnostic entities in vivo.

\section{Limitations of the Existing Routes of Administration}

Although nanotherapeutics has shown tremendous application potential, it still has some limitations [109-143] (Table 1). The brain is the most sensitive and complex organ and any non-specific 
distribution of drugs may result in complicated irreversible damage to the CNS. Nanoparticles are very small in dimension and could likely deliver drugs way over the tolerated levels by the brain, thereby delaying the clearance and resulting in severe toxic effects [144]. Therefore, intensive care is needed when considering the delivery of therapeutics using nanoparticles. The toxicity of nanoparticles relates to their shape, size, surface area, solubility, and dose, and oxidative stress generation is the most commonly reported toxicity [145]. It has been shown that iron oxide nanoparticles reduced the viability of the PC12 cell line, whereas they caused neuronal degeneration in vivo [146,147]. A study reported the non-specific distribution of silver nanoparticles in the brain, liver, and kidney upon long-term exposure [148]. To overcome these limitations, biodegradable polymeric nanoparticles are preferred these days which can offer easy drug delivery and surface modifications. It has been shown that the biodegradable polymeric nanoparticles are metabolically converted to biocompatible lactic acid, butanol, and 6-hydroxycaproic acid, all of which are considered safe by the US-FDA [149].

Table 1. Approaches for brain drug delivery.

\begin{tabular}{|c|c|c|c|c|}
\hline S. No & Approaches & Benefits & Drawbacks & References * \\
\hline 1 & Nanoparticles & $\begin{array}{c}\text { Target the brain using specific } \\
\text { physiological conditions; Actively } \\
\text { targeted drug delivery }\end{array}$ & Cross the BBB & [114-124] \\
\hline 2 & Gold nanoparticles & $\begin{array}{c}\text { Drug delivery systems, } x \text {-ray } \\
\text { imaging, photothermal and } \\
\text { photodynamic therapies }\end{array}$ & $\begin{array}{c}\text { Neurotoxic effects like astrogliosis, } \\
\text { increased seizure activity, and } \\
\text { judgement impairments }\end{array}$ & [81-87] \\
\hline 3 & $\begin{array}{c}\text { Silver } \\
\text { nanoparticles }\end{array}$ & $\begin{array}{l}\text { Drug delivery systems, } \\
\text { anti-inflammatory }\end{array}$ & Neurotoxic & [88-96] \\
\hline 4 & $\begin{array}{c}\text { Magnetic } \\
\text { nanoparticles }\end{array}$ & $\begin{array}{c}\text { Targeted drug/gene delivery, } \\
\text { contrast agents for MRI, } \\
\text { biosensors for diagnostic purpose, } \\
\text { hyperthermia as treatment } \\
\text { modality in cancer }\end{array}$ & $\begin{array}{l}\text { Insufficient size control } \\
\text { distribution, uncontrolled shape, } \\
\text { poor colloidal stability, } \\
\text { nonbiodegradability, limited } \\
\text { biocompatibility and cytotoxicity }\end{array}$ & [97-103] \\
\hline 5 & $\begin{array}{l}\text { Nanoparticles for } \\
\text { brain diagnostics } \\
\text { or imaging }\end{array}$ & $\begin{array}{l}\text { Cross the BBB through increasing } \\
\text { the permeability under diseased } \\
\text { states; Enhanced imaging }\end{array}$ & $\begin{array}{l}\text { Difficult understanding of } \\
\text { dynamic changes in the BBB, } \\
\text { Cross the BBB }\end{array}$ & [143] \\
\hline 6 & $\begin{array}{l}\text { Brain permeability } \\
\text { enhancers }\end{array}$ & Open the BBB transiently & $\begin{array}{l}\text { Mismatched results between } \\
\text { humans and rodents }\end{array}$ & [128-131] \\
\hline 7 & $\begin{array}{l}\text { Enhanced brain } \\
\text { drug uptake using } \\
\text { non-invasive } \\
\text { techniques }\end{array}$ & $\begin{array}{l}\text { Ability to open the } \mathrm{BBB} \text { and } \\
\text { reduce efflux transporters }\end{array}$ & Higher toxicity & [136] \\
\hline 8 & Viral vectors & $\begin{array}{l}\text { High transfecting efficiency of } \\
\text { genes }\end{array}$ & $\begin{array}{l}\text { Safety issues; direct injection to } \\
\text { brain; crossing the BBB; high dose } \\
\text { by intravenous route }\end{array}$ & [109-113] \\
\hline 9 & Exosomes & $\begin{array}{l}\text { Delivering the genes to CNS; } \\
\text { actively cross the BBB }\end{array}$ & $\begin{array}{l}\text { Difficult loading procedure; } \\
\text { require exosomes donor cells; } \\
\text { in vitro toxicity, poor } \\
\text { pharmacokinetics }\end{array}$ & [125] \\
\hline 10 & Niosomes & $\begin{array}{l}\text { Targeted drug delivery, reduced } \\
\text { dose is required, subsequent } \\
\text { decrease in side effects, improved } \\
\text { bioavailability, osmotically active } \\
\text { and stable }\end{array}$ & $\begin{array}{l}\text { Requires specialized equipment, } \\
\text { inefficient drug loading, time } \\
\text { consuming }\end{array}$ & [55-63] \\
\hline 11 & $\begin{array}{l}\text { Delivery via active } \\
\text { transporters in the } \\
\text { BBB }\end{array}$ & $\begin{array}{l}\text { Potently cross the BBB by } \\
\text { intravenous injection }\end{array}$ & Used for small molecules only & {$[126,127]$} \\
\hline 12 & $\begin{array}{l}\text { Delivery under } \\
\text { disease states } \\
\text { through permeable } \\
\text { BBB }\end{array}$ & Potentially cross the BBB & $\begin{array}{c}\text { Dynamic changes in the BBB and } \\
\text { their mechanisms are poorly } \\
\text { understood }\end{array}$ & $\begin{array}{c}{[133-135,137,} \\
138]\end{array}$ \\
\hline 13 & $\begin{array}{l}\text { Using altered } \\
\text { administration } \\
\text { routes }\end{array}$ & $\begin{array}{l}\text { Bypass the BBB through nasal } \\
\text { administration }\end{array}$ & Suitable for low dose only & [142] \\
\hline
\end{tabular}

* The numbers refer to the numbered references in the text. 


\section{Nose-to-Brain as an Alternate Therapeutic Route}

Although researchers have successfully explained active transport mechanisms from the blood into the CNS and enabled the BBB penetration of some drugs, additional challenges still exist. Several drugs, particularly macromolecules, are degraded in the gastrointestinal tract and/or undergo hepatic metabolism, which severely limits the bioactive drug reaching the blood stream [150,151]. It is not appropriate to increase the oral dose for compensation, because it leads to unacceptable gastrointestinal tract or systemic adverse effects. Generally, $100 \%$ bioactive drugs in the blood stream can be obtained via injections, but they are not the route of choice in many cases especially for treatment requiring frequent dosing or home administration [152]. This limitation is even more conspicuous for intrathecal drug administration. Hence, researchers have focused on nasal administration that can offer an alternate route into the systemic circulation for multiple drugs having low oral bioavailability, slow absorption, and slow onset of action (Figure 4) [153]. In this scenario, the nasal passage can be used as an attractive delivery route for CNS drugs that do pass the BBB. Moreover, it can also be used for drugs formulated to exploit active transport mechanisms to cross from the blood into the brain [154].

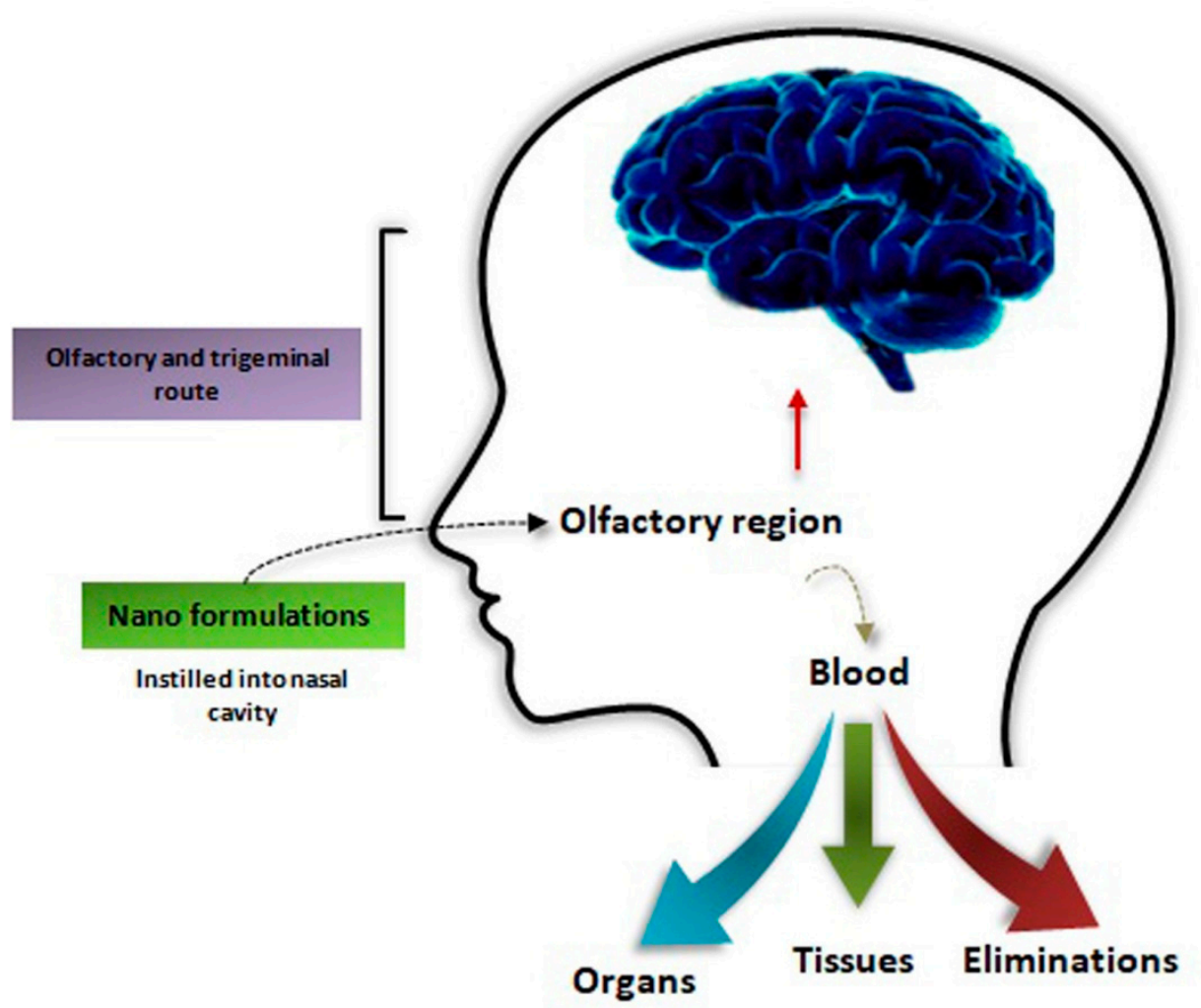

Figure 4. Brain targeting pathways in intranasal administration.

\section{Formulations for Nose-to-Brain Delivery}

Regarding the nose-to-brain delivery, various clinical and preclinical studies have been conducted to involve the use of drugs in solution and particulate dispersions [155-157]. Clinical studies have usually involved the use of a nasal drug delivery device, while most animal studies have been conducted in rodents.

\subsection{Solution Dosage Forms}

Studies have reported the use of drug molecules via the nose-to-brain route by simply dissolving it in an aqueous phase which produced significant pharmacological effects [155,157-159]. Intranasal delivery of insulin to the brain in an insulin solution was among the first trials of delivering peptides to 
the CNS [160]. Although clinical studies have shown a pharmacological response of drugs administered via the nose-to-brain route, preclinical studies reveal that only a small fraction of the administered dose is actually delivered to the brain. A study reported the delivery of radiolabeled interferon beta- $1 \mathrm{~b}$ in aqueous solution form to a monkey brain with a Cmax of $0.0064 \%$, and concluded that the drug delivery would be enhanced by adding absorption enhancers to the formulation [157]. Brain weight was supposed to be $1 \%$ of the animal's average body weight in all cases where the Cmax was shown as a percentage of the total dose [161]. A midpoint is considered as the representative body weight when a range of body weights are given. Another study reported the delivery of oxytocin solution to the brain via the nasal route with a Cmax of $0.003 \%$ of a $10 \mu \mathrm{g}$ dose being found in the brain [162]. Wang et al. delivered the DB213 (HIV replication inhibitor) solution to the rat brain with a Cmax that was estimated to be no more than $0.007 \%$ of the administered dose [163]. In comparison with similar computations following oral dosing where the Cmax is $0.24 \%-4.3 \%$ of the administered dose, these Cmax values are extremely low [164]. However, the addition of specialized excipients to these solutions boosts brain delivery via the nasal route. For example, when tetradecyl-b-D-maltoside (a penetration enhancer) was added to the protein solutions of serpin B2 and activin administered via the nose-to-brain route, neuroprotective activity was observed in a mouse model of brain injury [165]. A study showed that addition of a cell-penetrating peptide (CPP), L-penetratin, to the exendin-4 (glucagon-1 receptor agonist) solution resulted in delivery of exendin-4 to the hypothalamus and hippocampus on nasal delivery to normal mice and the activation of insulin signaling, whereas plain exendin- 4 solution and exendin-4 plus the inactive D-penetratin did not show brain delivery [166]. Moreover, intranasal exendin-4/CPP solutions plus supplemental insulin resulted in a therapeutic response against severe cognitive dysfunction in an SAMP8 mouse model of accelerated senescence [166].

Researchers have recommend the use of viscosity-building agents such as carboxymethylcellulose to enhance the nasal residence time of nasal solutions, and thus increase drug transport through the olfactory neurons [167]. It has been shown that when methotrexate solution containing carboxymethylcellulose was administered through the nasal route in combination with oral acetazolamide in a rat $9 \mathrm{~L}$ glioma model, significant tumor repression was observed when compared to drug delivery via an intraperitoneal route [167].

\subsection{Nanoparticles for Nose-to-Brain Delivery}

With conventional nasal solutions, very low drug transfer levels have been observed. Therefore, to address the low drug delivery problem, scientists are conducting experiments with nanoparticulate formulations like nanoemulsions, lipids, or polymer particles, which offer enhanced penetration and a longer residence time within the nasal cavity [156,168-176] (Table 2). It has been found that $100 \mathrm{~nm}$ nanoemulsion particles penetrated the olfactory bulb and reached the brain to a small extent, whereas $900 \mathrm{~nm}$ particles could not penetrate the brain, which indicated that a particle size cut-off may be operational for the delivery of nanoformulations beyond the olfactory bulb [168]. A transformational effect is known to occur on the level of drugs detected in the brain following intranasal delivery when it is converted from solution to particulate formulation [177]. The solution of a delta selective opioid agonist, leucine-5-enkephalin (LENK), initially failed to reach the rat brains in a considerable amount via the nasal route. However, the delivery was increased when LENK was formulated as an absorption-enhancing chitosan-based nanoparticle [156]. Compared to an intranasal dose of rivastigmine (a cholinesterase inhibitor used for the treatment of dementia) in solution, the emulsion form when administered intranasally led to a 5-fold increase in brain exposure [178]. The intranasal delivery of an anti-psychotic drug, quetiapine, resulted in a 2.57-fold increased Cmax when administered as chitosan-tripolyphosphate nanoparticles instead of the conventional solution [179]. From the commercial point of view, solution-based formulations exhibit a short half-life and are more prone to microbial contamination. Nanoformulations for nasal drug delivery can be further divided into solid lipid nanoparticles and nanoparticles prepared from chitosan derivatives or poly(L-lactide-co-glycolide), as described below [156,180-182]. 
Table 2. List of nanoformulations for intranasal drug delivery, with their potential advantages and limitations.

\begin{tabular}{|c|c|c|c|c|}
\hline S. No & Nanoformulation & Advantages & Limitations & References* \\
\hline 1 & $\begin{array}{c}\text { Polymeric } \\
\text { nanoparticles }\end{array}$ & Higher loading efficiency & Biocompatibility issues & [170] \\
\hline 2 & $\begin{array}{l}\text { Solid lipid } \\
\text { nanoparticles }\end{array}$ & $\begin{array}{l}\text { better control upon drug release } \\
\text { pattern; Improved bioavailability of } \\
\text { incorporated drug molecules }\end{array}$ & $\begin{array}{l}\text { Unpredictable gelatin tendency } \\
\text { and particle growth }\end{array}$ & [173] \\
\hline 3 & $\begin{array}{l}\text { Microemulsions } \\
\text { and nanoemulsions }\end{array}$ & $\begin{array}{l}\text { Thermodynamically stable; increased } \\
\text { rate of absorption; enhance } \\
\text { bioavailability }\end{array}$ & $\begin{array}{l}\text { Stabilization of nanoemulsions } \\
\text { require large concentration of } \\
\text { surfactants as well as high } \\
\text { energy input }\end{array}$ & {$[169,183-191]$} \\
\hline 4 & $\begin{array}{l}\text { Nanostructured } \\
\text { lipid carriers }\end{array}$ & $\begin{array}{l}\text { Non-toxic; high loading capacity; } \\
\text { controlled and targeted release }\end{array}$ & Issues with physical stability & [174] \\
\hline 5 & Polymeric micelles & $\begin{array}{l}\text { Low toxicity; High stability; High } \\
\text { dose loading }\end{array}$ & $\begin{array}{l}\text { Immature drug-entrapping } \\
\text { technology; complicated } \\
\text { polymer synthesis }\end{array}$ & [176] \\
\hline 6 & $\begin{array}{l}\text { Dendrimer-conjugate } \\
\text { nanoparticles }\end{array}$ & $\begin{array}{c}\text { Better biodistribution and } \\
\text { pharmacokinetics; targeted, site } \\
\text { specific and controlled drug release }\end{array}$ & Toxic & [174] \\
\hline 7 & $\begin{array}{l}\text { Polymer-lipid } \\
\text { hybrid } \\
\text { nanoparticles }\end{array}$ & $\begin{array}{l}\text { Targeted delivery; minimum side } \\
\text { effects; sustained release drug; low } \\
\text { frequency of administration }\end{array}$ & Storage and stability issues & [175] \\
\hline 8 & $\begin{array}{c}\text { Chitosan } \\
\text { nanoparticles }\end{array}$ & $\begin{array}{l}\text { Non-toxic; stable; biodegradable; } \\
\text { biocompatible; enhanced absorption }\end{array}$ & $\begin{array}{l}\text { Time consuming protocols of } \\
\text { synthesis; need organic solvents } \\
\text { in preparation method }\end{array}$ & [172] \\
\hline 9 & $\begin{array}{c}\text { PLGA } \\
\text { nanoparticles }\end{array}$ & $\begin{array}{l}\text { Minimum toxicity; deeper } \\
\text { penetration into the tissues; high } \\
\text { loading capacity; extended drug } \\
\text { release }\end{array}$ & Toxicity issues & [171] \\
\hline
\end{tabular}

* The numbers refer to the numbered references in the text.

\subsection{Lipid Nanoparticles}

Lipid nanoparticles comprise a lipid core stabilized by a surfactant. Lipid nanoparticles differ from oil-in-water emulsions in that they are solids at room temperature. They are prepared by melting the lipid, followed by size reduction and surfactant stabilization of the resulting particles in an aqueous disperse phase [192]. Lipid nanoparticles can be loaded with hydrophobic drugs and may be administered via the nasal route to deliver drugs to the brain. Valproic acid lipid nanoparticles, compared to the drug in solution form, delivered high drug dose to the brain, and prevented tonic-clonic partial seizures in a maximal electric shock seizure model; this effect was similar to intraperitoneal phenytoin [180]. The lipid nanoparticles are supposed to protect the drug from biological and/or chemical degradation, and from extracellular transport by P-gp efflux proteins, and may indeed promote drug transport by unknown mechanisms [193].

\subsection{Microemulsions and Nanoemulsions}

Microemulsions (MEs) are pseudo ternary systems which consist of oil, water and surfactant. They are frequently used in combination with co-surfactants. MEs are stable, single-phase swollen micellar solutions which form spontaneously, and can be utilized to incorporate a larger quantity of hydrophilic and/or lipophilic drug molecules [183]. Nanoemulsions (NEs) comprise of mixtures of oil, water and surfactant. These are kinetically stable, non-equilibrium systems, which do not essentially require the co-surfactants. NEs synthesis is not spontaneous but requires high energy input. NEs are also called mini-emulsions, submicron emulsions, or ultrafine emulsions [184]. MEs and NEs share similarity in size, however, they are different from each other regarding the method of preparation, composition, and concentrations of the components. It has been suggested that MEs and NEs enhance nose-to-brain delivery of drugs through the olfactory region $[185,186]$. Additionally, they offer dose uniformity and better sprayability advantages over other nano vectors for intranasal administration. It has been reported that compared to intravenous administration, ME of nimodipine (a calcium channel 
blocker) showed higher nimodipine concentration in the brain following intranasal administration [187]. A study has shown that olanzapine mucoadhesive NE resulted in high brain to plasma ratio than olanzapine nanoemulsion and olanzapine following intranasal administration [186]. Additionally, Vyas TK and co-workers reported similar findings with sumatriptan, clonazepam, resperidine and zolmitriptan MEs [188-191]. These studies suggest that direct nose-to-brain delivery of MEs and NEs may provide significant merits in many therapeutic situations where rapid and/or specific targeting of drugs to the CNS is required.

\subsection{Nanoparticles Composed of Chitosan and Chitosan Derivatives}

Chitosan has been shown to act as a penetration enhancer by temporarily opening intercellular tight junctions, and has been utilized in a number of nose-to-brain nanoformulations [194]. Although various reports have shown the enhanced delivery of drugs using chitosan nanoparticles, the exact mechanism of this enhanced drug delivery remains poorly understood [179]. Compared to an intranasal solution, quetiapine chitosan nanoparticles enhanced the drug delivery to the brain by 34\% [179]. It has been reported that intranasal chitosan nanoparticles of pramipexole better controlled motor deficits in a rotenone model of PD than the oral or solution dosage form of the drug [195]. Additionally, chitosan nanoparticles have also been shown to be used in gene therapies via nasal administration. For instance, chitosan-tripolyphosphate siRNA nanoparticles silenced galectin-1, a gene that drives chemoresistance and immune-therapy resistance on intranasal administration, resulting in increased survival in a mouse tumor model [181]. Chitosan nanoparticles prepared with a chitosan-mangafodipir (mangafodipir is a manganese dipyridoxyl diphosphate chelator) electrostatic complex showed effective delivery of siRNA to the olfactory bulb for gene silencing [196,197].

The delivery of nucleic acids to the brain via the nasal route is a breakthrough achievement. A chitosan amphiphile has been shown to deliver a labile peptide to the brain. When $N$-palmitoyl- $N$ monomethyl- $N, N$-dimethyl- $N, N, N$-trimethyl-6-O-glycolchitosan (Nanomerics' Molecular Envelope Technology-MET) nanoparticles encapsulating LENK were administered intranasally, it produced analgesia in all tested animals with exclusive central activity and no peptide detected in the periphery [156]. A study has reported that intranasal administration of MET-propofol formulations produced sedation in a healthy rat model [198]. Furthermore, MET is mucoadhesive, which prolongs the residence time of the formulation within the nares, leading to extended duration of drug action; however, it does not open tight junctions [164]. MET is also a penetration enhancer, and has shown enhanced penetration in the gut epithelium via particle uptake mechanisms [199,200]. Chitosan-based emulsions have been shown to improve drug deposition in the brain following intranasal delivery. For instance, $0.3 \%(w / v)$ chitosan significantly increased the brain deposition of zolmitriptan when administered in an oil-in-water emulsion [201]. It has been reported that when resveratrol lipid microparticles were coated with chitosan and administered intranasally as lipid particles at the dose of $60 \mu \mathrm{m}$ to a rat model, a dramatic and specific 6-fold increase, without any detectable systemic exposure, was observed in its distribution to the cerebrospinal fluid [202].

\subsection{Poly L-Lactide-co-Glycolide (PLGA) Nanoparticles}

PLGA is a globally approved polymer for use in the human drug delivery system because of its non-toxic and biodegradable nature [203]. PLGA may be used to prevent degradation of drugs in the nasal cavity and may be loaded with hydrophobic drugs; these properties have been exploited in nose-to-brain delivery [203]. It has been shown that olanzapine PLGA nanoparticles resulted in 10-times more Cmax and drug delivery to the brain than olanzapine solution [182]. A study reported that oxcarbazepine PLGA nanoparticles showed better pharmacokinetic behavior and superiorly reduced intraperitoneal pentylene tetrazole-induced seizures in a rat model than the drug in solution form [204]. It was shown that upon intranasal administration, a PLGA-poly(ethylene glycol) (PLGA-PEG) copolymer nanoparticle, conjugated with Solanum tuberosum lectin and loaded with basic fibroblast growth factor, improved cognition in a mouse AD model [205]. Interestingly, 
although PLGA nanoparticles have not been reported to be mucoadhesive or penetration enhancers, drug delivery to the brain is still enhanced through the nasal route. In a trial to coat the PLGA nanoparticles with chitosan, it was observed that their brain transport was altered and positively charged chitosan-coated PLGA nanoparticles appeared to move slower than plain negatively charged PLGA nanoparticles from the caudal to the rostral regions of the brain [206]. Another study developed huperzine A-loaded, mucoadhesive, and targeted PLGA nanoparticles with surface modification by lactoferrin-conjugated $N$-trimethylated chitosan for efficient intranasal delivery of huperzine A to the brain for AD treatment. These nanoparticles showed good sustained-release effect, adhesion, targeting ability, and a broad application prospect as a nasal drug delivery carrier [207]. These studies suggest that particle transport via the nose-to-brain route is highly affected by the particle surface chemistry. Furthermore, clarification of the different biological mechanisms of nose-to-brain delivery will assist in the design and development of various useful dosage forms.

\section{Limitation and Safety Consideration for the Nasal Formulations}

The intranasal-route of drug delivery is an attractive route which quickly and accurately accesses the brain. The intranasal route of drug delivery has multiple advantages such as BBB evasion; being non-invasive, convenient, and a patient-friendly route of drug administration; having faster onset of action, more precise drug targeting, more significant area of drug absorption; circumventing the hepatic first-pass metabolism of drug; and showing less systemic side effects [208-210]. However, the clinical application of intranasal formulations for brain drug delivery still has a long way to go. Poor drug permeability from the nasal mucosa, enzymatic degradation of the drug, mucociliary clearance, low drug retention time, and nasomucosal toxicity are some of the common limitations of the intranasal drug delivery [211,212]. Various controlled delivery systems, colloidal drug carriers, permeation enhancers, and other novel approaches have been employed to improve the drug permeability and absorption [213,214]. It has been shown that the use of a suitable mucoadhesive system like mucoadhesive polymers, viscous formulation, in situ gelatins, and hydrogel enhances the retention time and reduces mucociliary clearance [215]. Additionally, some protective measures are needed, like encapsulation in a nanocarrier system, which prevent enzymatic degradation of the drug. All these formulation strategies facilitate intranasal drug delivery; however, the clinical success of intranasal therapy remains limited because of the high and frequent dose of the formulation, hence irritating the nasal mucosa. Additionally, the protective barriers of the nasal mucosa limit the efficiency of intranasal therapy, and only $1 \%$ or $<1 \%$ of the drug reaches the brain after intranasal administration. Thus, it is essential to focus on the development of a suitable formulation to overcome these barriers [216].

Furthermore, the nature and efficacy of the drug and excipients should also be considered. Compared to the other routes, the nasal cavity allows only a small amount of formulation (100-200 $\mu \mathrm{L})$ at a time given its relatively low volume $\left(25 \mathrm{~cm}^{3}\right)$. Hence, a potent drug is required for intranasal drug delivery to the brain. Moreover, it is very important for excipients in a formulation to be biocompatible and not produce any aggressive odor [217]. Additionally, the tonicity, viscosity, and $\mathrm{pH}(5.0-6.5)$ of the formulation also play key roles in drug development $[216,218]$. Another key factor to be considered is the technique of administration that influences drug absorption by the brain. The formulation is prone to mucociliary clearance if it is deposited on the floor of the nasal cavity. It has been shown that the posterior and upper regions of the nasal cavity are responsible for drug absorption to the olfactory region or the brain, whereas the anterior region of the nasal cavity tends to displace the drug towards systemic circulation. Hence, a suitable delivery device such as a nasal dropper, needleless syringe, or spray is required to deliver the formulation in the appropriate region of the nasal cavity [219]. The currently available devices to target drugs to the brain are OptiMist ${ }^{\mathrm{TM}}$ (a breath actuator) and ViaNasa $^{\mathrm{TM}}$ (electronic atomizer) [216,220,221].

Many researchers have claimed successful, direct, and effective drug transfer from the nasal cavity to the brain although some reports have contradicted the hypothesis of direct drug delivery to the brain. Scientists from Leiden University did not find any evidence of direct nose-to-brain delivery 
of melatonin, estradiol, and vitamin B12, whereas another group of researchers reported significant amounts of these drugs in the brain after intranasal administration [222,223]. This discrepancy in results is likely because of the experimental conditions and formulation factors, as well as variable methodology used. Hence, it is essential to thoroughly understand all the formulation aspects for successful clinical application of intranasal drug delivery to the brain [222]. Despite significant successful research work, intranasal drug delivery requires more efforts for commercial availability of these drugs. Recent and on-going research has only focused on few issues, whereas the development of successful formulations requires an all-round and deep consideration and understanding.

\section{Future Prospective of Nose-to-Brain Delivery}

Treatment of neurological diseases remains one of the most significant challenges, and advances in nanotechnology have provided promising solutions to this challenge [224]. Based on the past few years' research, we can conclude that nanotechnology has gained considerable focus. Multiple nanocarriers such as solid lipid nanoparticles, liposomes, polymeric nanoparticles, dendrimers, nanogels, micelles, nanoemulsions, and nanosuspensions have been studied for the delivery of brain therapeutics [224]. It is expected that in the near future, more drugs in the form of nasal formulations intended for brain disorders will be commercially available [225]. However, this functional drug delivery mechanism to the brain is a potential area of research because there are still certain unresolved challenges during intranasal delivery. These include handling large molecular weight polar drugs such as peptides and proteins, low membrane permeability, mucocilliary clearance, and the possibility of an enzymatic degradation of the molecule in the lumen of the nasal cavity. These problems can be solved by focusing on bioadhesive excipients and absorption enhancers in the formulation. The current nanoparticle-based drug delivery technology should be improved further, so that it can be target oriented, safe, effective, and cost-effective. Additionally, development of CNS nanoformulations needs to focus on improving their BBB permeability, reducing neurotoxicity, and increasing their drug-trafficking performance and specificity for brain tissue using novel targeting moieties [224]. Furthermore, adequate clinical and preclinical trials to improve the intranasal delivery system are required. It is also not entirely clear how drugs are delivered directly to the brain; thus, further research is required to better understand the exact mechanism of drug passage through the intranasal route to specific brain areas. It is also important to pay attention to formulation strategies, drug delivery devices, new excipients development, and mucoadhesive characteristics of polymers, all of which could potentially improve bioavailability, prolong retention, and maximize the effects of the drugs. Additionally, toxicodynamic studies of drug and excipients and nanotoxicity of nanocarriers should also be extensively investigated [225].

\section{Conclusions}

Drug carriage and accessing the brain has always remained a significant challenge in the treatment of CNS disorders. The efficiency of CNS drugs becomes limited due to various physiological factors such as first pass effect, enzymatic degradation, presence of the BBB, inadequate blood perfusion, systemic clearance, peripheral side effects, and reduced bioavailability. The intranasal route offers many advantages and can hence overcome some of the limitations; it is thus a preferred, alternative drug administration route over the parental and oral routes. Currently, scientists have utilized different novel strategies such as targeting ligands, nanoparticulate systems, and mucoadhesive formulations to develop a promising intranasal drug delivery device with minimal toxicity and side effects. Most of the investigations are currently in preclinical or early clinical stages, and the successful claims are limited to animal models only. Very few investigations have expanded to human clinical trials; however, it is estimated that the intranasal route could be a future method for drug delivery to the brain. Our review has discussed the various scientific attempts in the development of an effective intranasal drug delivery system for the treatment of brain disorders. A large number of drugs, proteins, peptides, biological agents, and cells are presently under investigation for intranasal delivery awaiting successful outcomes. 
If clinical studies support such preclinical data, intranasal drug delivery can be a new beacon of hope for treatment of brain disorders.

Author Contributions: Y.S.L.: Conceptualization, Supervision; S.U.I. and M.B.A.: Writing-Original Draft; A.S.: Writing-Review and Editing, Visualization. All authors have read and agreed to the published version of the manuscript.

Funding: This research was funded by the National Research Foundation of Korea (NRF) grant funded by the Korea government (MSIT) (NRF- 2019R1A2C1003003).

Conflicts of Interest: The authors declare no conflict of interest, financial or otherwise.

\section{References}

1. Koshy, M.; Villano, J.L.; Dolecek, T.A.; Howard, A.; Mahmood, U.; Chmura, S.J.; Weichselbaum, R.R.; McCarthy, B.J. Improved survival time trends for glioblastoma using the SEER 17 population-based registries. J. Neuro-Oncol. 2012, 107, 207-212. [CrossRef]

2. Wang, J.; Gu, B.J.; Masters, C.L.; Wang, Y.-J. A systemic view of Alzheimer disease-Insights from amyloid- $\beta$ metabolism beyond the brain. Nat. Rev. Neurol. 2017, 13, 612. [CrossRef]

3. Poewe, W.; Seppi, K.; Tanner, C.M.; Halliday, G.M.; Brundin, P.; Volkmann, J.; Schrag, A.-E.; Lang, A.E. Parkinson disease. Nat. Rev. Dis. Primers 2017, 3, 17013. [CrossRef]

4. Cummings, J.; Mintzer, J.; Brodaty, H.; Sano, M.; Banerjee, S.; Devanand, D.; Gauthier, S.; Howard, R.; Lanctôt, K.; Lyketsos, C.G. Agitation in cognitive disorders: International Psychogeriatric Association provisional consensus clinical and research definition. Int. Psychogeriatr. 2015, 27, 7-17. [CrossRef]

5. Abbott, N.J.; Rönnbäck, L.; Hansson, E. Astrocyte-endothelial interactions at the blood-brain barrier. Nat. Rev. Neurosci. 2006, 7, 41. [CrossRef] [PubMed]

6. Greish, K. Enhanced Permeability and Retention (EPR) Effect for Anticancer Nanomedicine Drug Targeting. Methods Mol Biol. 2010, 624, 25-37.

7. De Jong, W.H.; Borm, P.J. Drug delivery and nanoparticles: Applications and hazards. Int. J. Nanomed. 2008, 3, 133. [CrossRef] [PubMed]

8. Mahmud, H.; Kasai, T.; Khayrani, A.C.; Asakura, M.; Oo, A.K.K.; Du, J.; Vaidyanath, A.; El-Ghlban, S.; Mizutani, A.; Seno, A. Targeting glioblastoma cells expressing CD44 with liposomes encapsulating doxorubicin and displaying chlorotoxin-IgG Fc fusion protein. Int. J. Mol. Sci. 2018, 19, 659. [CrossRef] [PubMed]

9. Kreuter, J.; Shamenkov, D.; Petrov, V.; Ramge, P.; Cychutek, K.; Koch-Brandt, C.; Alyautdin, R. Apolipoprotein-mediated transport of nanoparticle-bound drugs across the blood-brain barrier. J. Drug Target. 2002, 10, 317-325. [CrossRef]

10. Brightman, M.W.; Kaya, M. Permeable endothelium and the interstitial space of brain. Cell. Mol. Neurobiol. 2000, 20, 111-130. [CrossRef]

11. Kabanov, A.; Gendelman, H.E. Nanomedicine in the diagnosis and therapy of neurodegenerative disorders. Prog. Polym. Sci. 2007, 32, 1054-1082. [CrossRef] [PubMed]

12. Kanwar, J.R.; Sun, X.; Punj, V.; Sriramoju, B.; Mohan, R.R.; Zhou, S.-F.; Chauhan, A.; Kanwar, R.K. Nanoparticles in the treatment and diagnosis of neurological disorders: Untamed dragon with fire power to heal. Nanomed. Nanotechnol. Biol. Med. 2012, 8, 399-414. [CrossRef] [PubMed]

13. Nutt, J.G.; Carter, J.H.; Sexton, G.J. The dopamine transporter: Importance in Parkinson's disease. Ann. Neurol. 2004, 55, 766-773. [CrossRef] [PubMed]

14. Spillantini, M.G.; Schmidt, M.L.; Lee, V.M.-Y.; Trojanowski, J.Q.; Jakes, R.; Goedert, M. $\alpha$-Synuclein in Lewy bodies. Nature 1997, 388, 839. [CrossRef] [PubMed]

15. Md, S.; Haque, S.; Sahni, J.K.; Baboota, S.; Ali, J. New non-oral drug delivery systems for Parkinson's disease treatment. Expert Opin. Drug Deliv. 2011, 8, 359-374. [CrossRef]

16. Agid, Y.; Destee, A.; Durif, F.; Montastruc, J.; Pollak, P.; Group, F.T.S. Tolcapone, bromocriptine, and Parkinson's disease. Lancet 1997, 350, 712-713. [CrossRef]

17. Thanvi, B.; Lo, N.; Robinson, T. Levodopa-induced dyskinesia in Parkinson's disease: Clinical features, pathogenesis, prevention and treatment. Postgrad. Med J. 2007, 83, 384-388. [CrossRef] 
18. Kumar, A.; Singh, A. A review on Alzheimer's disease pathophysiology and its management: An update. Pharmacol. Rep. 2015, 67, 195-203. [CrossRef]

19. Akiyama, H.; Barger, S.; Barnum, S.; Bradt, B.; Bauer, J.; Cole, G.M.; Cooper, N.R.; Eikelenboom, P.; Emmerling, M.; Fiebich, B.L. Inflammation and Alzheimer's disease. Neurobiol. Aging 2000, 21, $383-421$. [CrossRef]

20. Aisen, P.S.; Gauthier, S.; Ferris, S.H.; Saumier, D.; Haine, D.; Garceau, D.; Duong, A.; Suhy, J.; Oh, J.; Lau, W.C. Tramiprosate in mild-to-moderate Alzheimer's disease-A randomized, double-blind, placebo-controlled, multi-centre study (the Alphase Study). Arch. Med Sci. Am. 2011, 7, 102. [CrossRef]

21. Janusz, M.; Zablocka, A. Colostral proline-rich polypeptides-immunoregulatory properties and prospects of therapeutic use in Alzheimer's disease. Curr. Alzheimer Res. 2010, 7, 323-333. [CrossRef] [PubMed]

22. Rojo, L.E.; Alzate-Morales, J.; Saavedra, I.N.; Davies, P.; Maccioni, R.B. Selective interaction of lansoprazole and astemizole with tau polymers: Potential new clinical use in diagnosis of Alzheimer's disease. J. Alzheimer's Dis. 2010, 19, 573-589. [CrossRef] [PubMed]

23. Kandimalla, R.; Reddy, P.H. Therapeutics of neurotransmitters in Alzheimer's disease. J. Alzheimer's Dis. 2017, 57, 1049-1069. [CrossRef] [PubMed]

24. Das, K.K.; Kumar, R. Pediatric Glioblastoma. In Glioblastoma [Internet]; Codon Publications: Brisbane, Australia, 2017.

25. Hanif, F.; Muzaffar, K.; Perveen, K.; Malhi, S.M.; Simjee, S.U. Glioblastoma multiforme: A review of its epidemiology and pathogenesis through clinical presentation and treatment. Asian Pac. J. Cancer Prev. Apjcp 2017, 18, 3. [PubMed]

26. Lee, C.; Hwang, H.S.; Lee, S.; Kim, B.; Kim, J.O.; Oh, K.T.; Lee, E.S.; Choi, H.G.; Youn, Y.S. Rabies virus-inspired silica-coated gold nanorods as a photothermal therapeutic platform for treating brain tumors. Adv. Mater. 2017, 29, 1605563. [CrossRef] [PubMed]

27. Dixit, S.; Novak, T.; Miller, K.; Zhu, Y.; Kenney, M.E.; Broome, A.-M. Transferrin receptor-targeted theranostic gold nanoparticles for photosensitizer delivery in brain tumors. Nanoscale 2015, 7, 1782-1790. [CrossRef]

28. Guo, J.; Gao, X.; Su, L.; Xia, H.; Gu, G.; Pang, Z.; Jiang, X.; Yao, L.; Chen, J.; Chen, H. Aptamer-functionalized PEG-PLGA nanoparticles for enhanced anti-glioma drug delivery. Biomaterials 2011, 32, 8010-8020. [CrossRef]

29. Gao, H.; Qian, J.; Cao, S.; Yang, Z.; Pang, Z.; Pan, S.; Fan, L.; Xi, Z.; Jiang, X.; Zhang, Q. Precise glioma targeting of and penetration by aptamer and peptide dual-functioned nanoparticles. Biomaterials 2012, 33, 5115-5123. [CrossRef]

30. Madhankumar, A.; Slagle-Webb, B.; Mintz, A.; Sheehan, J.M.; Connor, J.R. Interleukin-13 receptor-targeted nanovesicles are a potential therapy for glioblastoma multiforme. Mol. Cancer Ther. 2006, 5, 3162-3169. [CrossRef]

31. Qin, L.; Wang, C.Z.; Fan, H.J.; Zhang, C.J.; Zhang, H.W.; Lv, M.H.; Cui, S.D. A dual-targeting liposome conjugated with transferrin and arginine-glycine-aspartic acid peptide for glioma-targeting therapy. Oncol. Lett. 2014, 8, 2000-2006. [CrossRef]

32. Huang, B.; Zhang, H.; Gu, L.; Ye, B.; Jian, Z.; Stary, C.; Xiong, X. Advances in immunotherapy for glioblastoma multiforme. J. Immunol. Res. 2017, 2017, 3597613. [CrossRef]

33. Devinsky, O.; Vezzani, A.; O’Brien, T.J.; Jette, N.; Scheffer, I.E.; de Curtis, M.; Perucca, P. Epilepsy. Nat. Rev. Dis. Primers 2018, 4, 18024. [CrossRef]

34. Fisher, R.S.; Acevedo, C.; Arzimanoglou, A.; Bogacz, A.; Cross, J.H.; Elger, C.E.; Engel, J., Jr.; Forsgren, L.; French, J.A.; Glynn, M. ILAE official report: A practical clinical definition of epilepsy. Epilepsia 2014, 55, 475-482. [CrossRef]

35. Sizemore, G.; Lucke-Wold, B.; Rosen, C.; Simpkins, J.W.; Bhatia, S.; Sun, D. Temporal lobe epilepsy, stroke, and traumatic brain injury: Mechanisms of hyperpolarized, depolarized, and flow-through ion channels utilized as tri-coordinate biomarkers of electrophysiologic dysfunction. OBM Neurobiol. 2018, 2, 9. [CrossRef]

36. Stafstrom, C.E.; Carmant, L. Seizures and epilepsy: An overview for neuroscientists. Cold Spring Harb. Perspect. Med. 2015, 5, a022426. [CrossRef]

37. Fisher, R.S.; Cross, J.H.; French, J.A.; Higurashi, N.; Hirsch, E.; Jansen, F.E.; Lagae, L.; Moshé, S.L.; Peltola, J.; Roulet Perez, E. Operational classification of seizure types by the International League Against Epilepsy: Position Paper of the ILAE Commission for Classification and Terminology. Epilepsia 2017, 58, 522-530. [CrossRef]

38. Love, S. Demyelinating diseases. J. Clin. Pathol. 2006, 59, 1151-1159. [CrossRef] 
39. Filippi, M.; Bar-Or, A.; Piehl, F.; Preziosa, P.; Solari, A.; Vukusic, S.; Rocca, M.A. Multiple sclerosis. Nat. Rev. Dis. Primers 2018, 4, 43. [CrossRef]

40. Shehzad, A.; Islam, S.U.; Lee, Y.S. Chapter 24-Curcumin and Inflammatory Brain Diseases. In Curcumin for Neurological and Psychiatric Disorders; Farooqui, T., Farooqui, A.A., Eds.; Academic Press: Cambridge, MA, USA, 2019; pp. 437-458.

41. Ferguson, B.; Matyszak, M.K.; Esiri, M.M.; Perry, V.H. Axonal damage in acute multiple sclerosis lesions. Brain J. Neurol. 1997, 120, 393-399. [CrossRef]

42. Michel, L.; Touil, H.; Pikor, N.B.; Gommerman, J.L.; Prat, A.; Bar-Or, A. B cells in the multiple sclerosis central nervous system: Trafficking and contribution to CNS-compartmentalized inflammation. Front. Immunol. 2015, 6, 636. [CrossRef]

43. Eunson, P. Aetiology and epidemiology of cerebral palsy. Paediatr. Child Health 2012, 22, 361-366. [CrossRef]

44. Graham, H.K.; Rosenbaum, P.; Paneth, N.; Dan, B.; Lin, J.-P.; Damiano, D.L.; Becher, J.G.; Gaebler-Spira, D.; Colver, A.; Reddihough, D.S.; et al. Cerebral palsy. Nat. Rev. Dis. Primers 2016, 2, 15082. [CrossRef]

45. Blair, E.; Watson, L. Epidemiology of cerebral palsy. Semin Fetal Neonatal Med. 2006, 11, 117-125. [CrossRef]

46. Patravale, V.; Date, A.A.; Kulkarni, R. Nanosuspensions: A promising drug delivery strategy. J. Pharm. Pharmacol. 2004, 56, 827-840. [CrossRef]

47. Müller, R.H.; Jacobs, C.; Kayser, O. Nanosuspensions as particulate drug formulations in therapy: Rationale for development and what we can expect for the future. Adv. Drug Deliv. Rev. 2001, 47, 3-19. [CrossRef]

48. Sharma, A.; Garg, T.; Aman, A.; Panchal, K.; Sharma, R.; Kumar, S.; Markandeywar, T. Nanogel—An advanced drug delivery tool: Current and future. Artif. Cells Nanomed. Biotechnol. 2016, 44, 165-177. [CrossRef]

49. Yallapu, M.M.; Jaggi, M.; Chauhan, S.C. Design and engineering of nanogels for cancer treatment. Drug Discov. Today 2011, 16, 457-463. [CrossRef]

50. Asadian-Birjand, M.; Sousa-Herves, A.; Steinhilber, D.; Cuggino, J.C.; Calderon, M. Functional nanogels for biomedical applications. Curr. Med. Chem. 2012, 19, 5029-5043. [CrossRef]

51. De Martimprey, H.; Vauthier, C.; Malvy, C.; Couvreur, P. Polymer nanocarriers for the delivery of small fragments of nucleic acids: Oligonucleotides and siRNA. Eur. J. Pharm. Biopharm. 2009, 71, 490-504. [CrossRef]

52. Vinogradov, S.V.; Batrakova, E.V.; Kabanov, A.V. Nanogels for oligonucleotide delivery to the brain. Bioconjugate Chem. 2004, 15, 50-60. [CrossRef]

53. Zylberberg, C.; Matosevic, S. Pharmaceutical liposomal drug delivery: A review of new delivery systems and a look at the regulatory landscape. Drug Deliv. 2016, 23, 3319-3329. [CrossRef] [PubMed]

54. Mourtas, S.; Canovi, M.; Zona, C.; Aurilia, D.; Niarakis, A.; La Ferla, B.; Salmona, M.; Nicotra, F.; Gobbi, M.; Antimisiaris, S.G. Curcumin-decorated nanoliposomes with very high affinity for amyloid- $\beta 1-42$ peptide. Biomaterials 2011, 32, 1635-1645. [CrossRef] [PubMed]

55. Ag Seleci, D.; Seleci, M.; Walter, J.-G.; Stahl, F.; Scheper, T. Niosomes as nanoparticular drug carriers: Fundamentals and recent applications. J. Nanomater. 2016, 2016, 7372306. [CrossRef]

56. Mahale, N.; Thakkar, P.; Mali, R.; Walunj, D.; Chaudhari, S. Niosomes: Novel sustained release nonionic stable vesicular systems-An overview. Adv. Colloid Interface Sci. 2012, 183, 46-54. [CrossRef] [PubMed]

57. Moghassemi, S.; Hadjizadeh, A. Nano-niosomes as nanoscale drug delivery systems: An illustrated review. J. Control. Release 2014, 185, 22-36. [CrossRef] [PubMed]

58. Gharbavi, M.; Amani, J.; Kheiri-Manjili, H.; Danafar, H.; Sharafi, A. Niosome: A promising nanocarrier for natural drug delivery through blood-brain barrier. Adv. Pharmacol. Pharm. Sci. 2018, 2018, 6847971. [CrossRef] [PubMed]

59. De, A.; Venkatesh, N.; Senthil, M.; Sanapalli, B.K.R.; Shanmugham, R.; Karri, V.V.S.R. Smart niosomes of temozolomide for enhancement of brain targeting. Nanobiomedicine 2018, 5, 1849543518805355. [CrossRef]

60. Khallaf, R.A.; Aboud, H.M.; Sayed, O.M. Surface modified niosomes of olanzapine for brain targeting via nasal route; preparation, optimization, and in vivo evaluation. J. Liposome Res. 2019, 1-11. [CrossRef]

61. Rinaldi, F.; Seguella, L.; Gigli, S.; Hanieh, P.N.; Del Favero, E.; Cantù, L.; Pesce, M.; Sarnelli, G.; Marianecci, C.; Esposito, G.; et al. inPentasomes: An innovative nose-to-brain pentamidine delivery blunts MPTP parkinsonism in mice. J. Control. Release 2019, 294, 17-26. [CrossRef]

62. Rinaldi, F.; Hanieh, P.N. Chitosan Glutamate-Coated Niosomes: A Proposal for Nose-to-Brain Delivery. Pharmaceutics 2018, 10, 38. [CrossRef] 
63. Mathure, D.; Madan, J.R.; Gujar, K.N.; Tupsamundre, A.; Ranpise, H.A.; Dua, K. Formulation and Evaluation of Niosomal in situ Nasal Gel of a Serotonin Receptor Agonist, Buspirone Hydrochloride for the Brain Delivery via Intranasal Route. Pharm. Nanotechnol. 2018, 6, 69-78. [CrossRef] [PubMed]

64. Kumari, A.; Yadav, S.K.; Yadav, S.C. Biodegradable polymeric nanoparticles based drug delivery systems. Colloids Surf. B Biointerfaces 2010, 75, 1-18. [CrossRef] [PubMed]

65. Mayer, C. Nanocapsules as drug delivery systems. Int. J. Artif. Organs 2005, 28, 1163-1171. [CrossRef] [PubMed]

66. Iqubal, M.K.; Iqubal, A.; Shuaib, M.; Shahryar, M. An exquisite technology of pharmaceutical science: Nanotechnology. Indo Am. J. Pharm. Res. 2015, 5, 3528-3540.

67. Behan, N.; Birkinshaw, C.; Clarke, N. Poly n-butyl cyanoacrylate nanoparticles: A mechanistic study of polymerisation and particle formation. Biomaterials 2001, 22, 1335-1344. [CrossRef]

68. Bernardi, A.; Frozza, R.L.; Horn, A.P.; Campos, M.M.; Calixto, J.B.; Salbego, C.; Pohlmann, A.R.; Guterres, S.S.; Battastini, A.M.O. Protective effects of indomethacin-loaded nanocapsules against oxygen-glucose deprivation in organotypic hippocampal slice cultures: Involvement of neuroinflammation. Neurochem. Int. 2010, 57, 629-636. [CrossRef]

69. O'Reilly, R.K.; Hawker, C.J.; Wooley, K.L. Cross-linked block copolymer micelles: Functional nanostructures of great potential and versatility. Chem. Soc. Rev. 2006, 35, 1068-1083. [CrossRef]

70. Sriramoju, B.; Kanwar, R.K.; Kanwar, J.R. Nanomedicine based nanoparticles for neurological disorders. Curr. Med. Chem. 2014, 21, 4154-4168. [CrossRef]

71. Harada-Shiba, M.; Yamauchi, K.; Harada, A.; Takamisawa, I.; Shimokado, K.; Kataoka, K. Polyion complex micelles as vectors in gene therapy-pharmacokinetics and in vivo gene transfer. Gene Ther. 2002, 9, 407. [CrossRef]

72. Pai, A.S.; Rubinstein, I.; Önyüksel, H. PEGylated phospholipid nanomicelles interact with $\beta$-amyloid (1-42) and mitigate its $\beta$-sheet formation, aggregation and neurotoxicity in vitro. Peptides 2006, 27, 2858-2866. [CrossRef]

73. Torchilin, V.P. Micellar nanocarriers: Pharmaceutical perspectives. Pharm. Res. 2007, 24, 1. [CrossRef]

74. Salata, O.V. Applications of nanoparticles in biology and medicine. J. Nanobiotechnol. 2004, 2, 3. [CrossRef]

75. Zhou, J.; Ralston, J.; Sedev, R.; Beattie, D.A. Functionalized gold nanoparticles: Synthesis, structure and colloid stability. J. Colloid Interface Sci. 2009, 331, 251-262. [CrossRef]

76. McBain, S.C.; Yiu, H.H.; Dobson, J. Magnetic nanoparticles for gene and drug delivery. Int. J. Nanomed. 2008, 3,169 .

77. Doria, G.; Conde, J.; Veigas, B.; Giestas, L.; Almeida, C.; Assunção, M.; Rosa, J.; Baptista, P.V. Noble metal nanoparticles for biosensing applications. Sensors 2012, 12, 1657-1687. [CrossRef]

78. Mody, V.V.; Siwale, R.; Singh, A.; Mody, H.R. Introduction to metallic nanoparticles. J. Pharm. Bioallied Sci. 2010, 2, 282. [CrossRef]

79. Dinali, R.; Ebrahiminezhad, A.; Manley-Harris, M.; Ghasemi, Y.; Berenjian, A. Iron oxide nanoparticles in modern microbiology and biotechnology. Crit. Rev. Microbiol. 2017, 43, 493-507. [CrossRef]

80. Ghosh, P.; Han, G.; De, M.; Kim, C.K.; Rotello, V.M. Gold nanoparticles in delivery applications. Adv. Drug Deliv. Rev. 2008, 60, 1307-1315. [CrossRef]

81. Ajnai, G.; Chiu, A.; Kan, T.; Cheng, C.-C.; Tsai, T.-H.; Chang, J. Trends of gold nanoparticle-based drug delivery system in cancer therapy. J. Exp. Clin. Med. 2014, 6, 172-178. [CrossRef]

82. Almeida, J.P.M.; Chen, A.L.; Foster, A.; Drezek, R. In vivo biodistribution of nanoparticles. Nanomedicine 2011, 6, 815-835. [CrossRef]

83. Gao, Y.; Li, Y. Gold nanostructures for cancer imaging and therapy. In Advances in Nanotheranostics I; Springer: Berlin, Germany, 2016; pp. 53-101.

84. Guo, R.; Zhang, L.; Qian, H.; Li, R.; Jiang, X.; Liu, B. Multifunctional nanocarriers for cell imaging, drug delivery, and near-IR photothermal therapy. Langmuir 2010, 26, 5428-5434. [CrossRef] [PubMed]

85. Sukumar, U.K.; Bose, R.J.C.; Malhotra, M.; Babikir, H.A.; Afjei, R.; Robinson, E.; Zeng, Y.; Chang, E.; Habte, F.; Sinclair, R.; et al. Intranasal delivery of targeted polyfunctional gold-iron oxide nanoparticles loaded with therapeutic microRNAs for combined theranostic multimodality imaging and presensitization of glioblastoma to temozolomide. Biomaterials 2019, 218, 119342. [CrossRef] [PubMed] 
86. Salem, H.F.; Kharshoum, R.M.; Abou-Taleb, H.A.; Naguib, D.M. Brain targeting of resveratrol through intranasal lipid vesicles labelled with gold nanoparticles: In vivo evaluation and bioaccumulation investigation using computed tomography and histopathological examination. J. Drug Target. 2019, 27, 1127-1134. [CrossRef] [PubMed]

87. Ealias, A.M.; Saravanakumar, M. A review on the classification, characterisation, synthesis of nanoparticles and their application. Proc. IOP Conf. Ser. Mater. Sci. Eng. 2017, 263, 032019.

88. Arora, S.; Jain, J.; Rajwade, J.; Paknikar, K. Cellular responses induced by silver nanoparticles: In vitro studies. Toxicol. Lett. 2008, 179, 93-100. [CrossRef]

89. Kim, H.R.; Kim, M.J.; Lee, S.Y.; Oh, S.M.; Chung, K.H. Genotoxic effects of silver nanoparticles stimulated by oxidative stress in human normal bronchial epithelial (BEAS-2B) cells. Mutat. Res. /Genet. Toxicol. Environ. Mutagen. 2011, 726, 129-135. [CrossRef]

90. Tang, J.; Xiong, L.; Zhou, G.; Wang, S.; Wang, J.; Liu, L.; Li, J.; Yuan, F.; Lu, S.; Wan, Z. Silver nanoparticles crossing through and distribution in the blood-brain barrier in vitro. J. Nanosci. Nanotechnol. 2010, 10, 6313-6317. [CrossRef]

91. Loeschner, K.; Hadrup, N.; Qvortrup, K.; Larsen, A.; Gao, X.; Vogel, U.; Mortensen, A.; Lam, H.R.; Larsen, E.H. Distribution of silver in rats following 28 days of repeated oral exposure to silver nanoparticles or silver acetate. Part. Fibre Toxicol. 2011, 8, 18. [CrossRef]

92. Sung, J.H.; Ji, J.H.; Park, J.D.; Yoon, J.U.; Kim, D.S.; Jeon, K.S.; Song, M.Y.; Jeong, J.; Han, B.S.; Han, J.H. Subchronic inhalation toxicity of silver nanoparticles. Toxicol. Sci. 2009, 108, 452-461. [CrossRef]

93. Patchin, E.S.; Anderson, D.S.; Silva, R.M.; Uyeminami, D.L.; Scott, G.M.; Guo, T.; Van Winkle, L.S.; Pinkerton, K.E. Size-Dependent Deposition, Translocation, and Microglial Activation of Inhaled Silver Nanoparticles in the Rodent Nose and Brain. Environ. Health Perspect. 2016, 124, 1870-1875. [CrossRef]

94. Falconer, J.L.; Grainger, D.W. In vivo comparisons of silver nanoparticle and silver ion transport after intranasal delivery in mice. J. Control. Release 2018, 269, 1-9. [CrossRef] [PubMed]

95. Sun, C.; Yin, N.; Wen, R.; Liu, W.; Jia, Y.; Hu, L.; Zhou, Q.; Jiang, G. Silver nanoparticles induced neurotoxicity through oxidative stress in rat cerebral astrocytes is distinct from the effects of silver ions. Neurotoxicology 2016, 52, 210-221. [CrossRef] [PubMed]

96. Gonzalez-Carter, D.A.; Leo, B.F.; Ruenraroengsak, P.; Chen, S.; Goode, A.E.; Theodorou, I.G.; Chung, K.F.; Carzaniga, R.; Shaffer, M.S.P.; Dexter, D.T.; et al. Silver nanoparticles reduce brain inflammation and related neurotoxicity through induction of $\mathrm{H}_{2} \mathrm{~S}$-synthesizing enzymes. Sci. Rep. 2017, 7, 42871. [CrossRef]

97. Lakshmanan, S.; Gupta, G.K.; Avci, P.; Chandran, R.; Sadasivam, M.; Jorge, A.E.S.; Hamblin, M.R. Physical energy for drug delivery; poration, concentration and activation. Adv. Drug Deliv. Rev. 2014, 71, 98-114. [CrossRef] [PubMed]

98. Dan, M.; Bae, Y.; Pittman, T.A.; Yokel, R.A. Alternating magnetic field-induced hyperthermia increases iron oxide nanoparticle cell association/uptake and flux in blood-brain barrier models. Pharm. Res. 2015, 32, 1615-1625. [CrossRef] [PubMed]

99. Villate-Beitia, I.; Puras, G.; Soto-Sánchez, C.; Agirre, M.; Ojeda, E.; Zarate, J.; Fernández, E.; Pedraz, J.L. Non-viral vectors based on magnetoplexes, lipoplexes and polyplexes for VEGF gene delivery into central nervous system cells. Int. J. Pharm. 2017, 521, 130-140. [CrossRef] [PubMed]

100. Bu, L.; Xie, J.; Chen, K.; Huang, J.; Aguilar, Z.P.; Wang, A.; Sun, K.W.; Chua, M.S.; So, S.; Cheng, Z. Assessment and comparison of magnetic nanoparticles as MRI contrast agents in a rodent model of human hepatocellular carcinoma. Contrast Media Mol. Imaging 2012, 7, 363-372. [CrossRef]

101. Niu, S.; Zhang, L.-K.; Zhang, L.; Zhuang, S.; Zhan, X.; Chen, W.-Y.; Du, S.; Yin, L.; You, R.; Li, C.-H. Inhibition by multifunctional magnetic nanoparticles loaded with alpha-synuclein RNAi plasmid in a Parkinson's disease model. Theranostics 2017, 7, 344. [CrossRef]

102. Sobh, M.; Shalash, A.; Mohamed, W.M. Effect of intranasal stem cell administration on the nigrostriatal system in a mouse model of Parkinson's disease. Exp. Ther. Med. 2017, 13, 976-982.

103. Chung, T.-H.; Hsu, S.-C.; Wu, S.-H.; Hsiao, J.-K.; Lin, C.-P.; Yao, M.; Huang, D.-M. Dextran-coated iron oxide nanoparticle-improved therapeutic effects of human mesenchymal stem cells in a mouse model of Parkinson's disease. Nanoscale 2018, 10, 2998-3007. [CrossRef]

104. Tekade, R.K.; Kumar, P.V.; Jain, N.K. Dendrimers in oncology: An expanding horizon. Chem. Rev. 2008, 109, 49-87. [CrossRef] [PubMed] 
105. Marcos, M.; Giménez, R.; Serrano, J.L.; Donnio, B.; Heinrich, B.; Guillon, D. Dendromesogens: Liquid crystal organizations of poly (amidoamine) dendrimers versus starburst structures. Chem. Eur. J. 2001, 7, 1006-1013. [CrossRef]

106. Nanjwade, B.K.; Bechra, H.M.; Derkar, G.K.; Manvi, F.; Nanjwade, V.K. Dendrimers: Emerging polymers for drug-delivery systems. Eur. J. Pharm. Sci. 2009, 38, 185-196. [CrossRef] [PubMed]

107. Lee, C.C.; MacKay, J.A.; Fréchet, J.M.; Szoka, F.C. Designing dendrimers for biological applications. Nat. Biotechnol. 2005, 23, 1517. [CrossRef] [PubMed]

108. Aillon, K.L.; Xie, Y.; El-Gendy, N.; Berkland, C.J.; Forrest, M.L. Effects of nanomaterial physicochemical properties on in vivo toxicity. Adv. Drug Deliv. Rev. 2009, 61, 457-466. [CrossRef] [PubMed]

109. Check, E. Gene Therapy Put on Hold as Third Child Develops Cancer; Nature Publishing Group: Berlin, Germany, 2005.

110. Mingozzi, F.; High, K.A. Immune responses to AAV vectors: Overcoming barriers to successful gene therapy. Blood 2013, 122, 23-36. [CrossRef]

111. Gray, S.J.; Woodard, K.T.; Samulski, R.J. Viral vectors and delivery strategies for CNS gene therapy. Ther. Deliv. 2010, 1, 517-534. [CrossRef]

112. Vagner, T.; Dvorzhak, A.; Wójtowicz, A.M.; Harms, C.; Grantyn, R. Systemic application of AAV vectors targeting GFAP-expressing astrocytes in Z-Q175-KI Huntington's disease mice. Mol. Cell. Neurosci. 2016, 77, 76-86. [CrossRef]

113. Tanabe, S.; Inoue, K.-i.; Tsuge, H.; Uezono, S.; Nagaya, K.; Fujiwara, M.; Kato, S.; Kobayashi, K.; Takada, M. The use of an optimized chimeric envelope glycoprotein enhances the efficiency of retrograde gene transfer of a pseudotyped lentiviral vector in the primate brain. Neurosci. Res. 2017, 120, 45-52. [CrossRef]

114. Saraiva, C.; Praça, C.; Ferreira, R.; Santos, T.; Ferreira, L.; Bernardino, L. Nanoparticle-mediated brain drug delivery: Overcoming blood-brain barrier to treat neurodegenerative diseases. J. Control. Release 2016, 235, 34-47. [CrossRef]

115. Wohlfart, S.; Gelperina, S.; Kreuter, J. Transport of drugs across the blood-brain barrier by nanoparticles. J. Control. Release 2012, 161, 264-273. [CrossRef] [PubMed]

116. Jiang, Y.; Brynskikh, A.M.; Devika, S.; Kabanov, A.V. SOD1 nanozyme salvages ischemic brain by locally protecting cerebral vasculature. J. Control. Release 2015, 213, 36-44. [CrossRef] [PubMed]

117. Medina, D.X.; Householder, K.T.; Ceton, R.; Kovalik, T.; Heffernan, J.M.; Shankar, R.V.; Bowser, R.P.; Wechsler-Reya, R.J.; Sirianni, R.W. Optical barcoding of PLGA for multispectral analysis of nanoparticle fate in vivo. J. Control. Release 2017, 253, 172-182. [CrossRef] [PubMed]

118. Kreuter, J. Mechanism of polymeric nanoparticle-based drug transport across the blood-brain barrier (BBB). J. Microencapsul. 2013, 30,49-54. [CrossRef]

119. Georgieva, J.; Hoekstra, D.; Zuhorn, I. Smuggling drugs into the brain: An overview of ligands targeting transcytosis for drug delivery across the blood-brain barrier. Pharmaceutics 2014, 6, 557-583. [CrossRef]

120. Candela, P.; Gosselet, F.; Miller, F.; Buee-Scherrer, V.; Torpier, G.; Cecchelli, R.; Fenart, L. Physiological pathway for low-density lipoproteins across the blood-brain barrier: Transcytosis through brain capillary endothelial cells in vitro. Endothelium 2008, 15, 254-264. [CrossRef]

121. Schenk, G.J.; de Vries, H.E. Altered blood-brain barrier transport in neuro-inflammatory disorders. Drug Discov. Today Technol. 2016, 20, 5-11. [CrossRef]

122. Jeong, S.Y.; Crooks, D.R.; Wilson-Ollivierre, H.; Ghosh, M.C.; Sougrat, R.; Lee, J.; Cooperman, S.; Mitchell, J.B.; Beaumont, C.; Rouault, T.A. Iron insufficiency compromises motor neurons and their mitochondrial function in Irp2-null mice. PLoS ONE 2011, 6, e25404. [CrossRef]

123. Ho, L.; Yemul, S.; Knable, L.; Katsel, P.; Zhao, R.; Haroutunian, V.; Pasinetti, G.M. Insulin receptor expression and activity in the brains of nondiabetic sporadic Alzheimer's disease cases. Int. J. Alzheimer's Dis. 2012, 2012. [CrossRef]

124. Song, Q.; Song, H.; Xu, J.; Huang, J.; Hu, M.; Gu, X.; Chen, J.; Zheng, G.; Chen, H.; Gao, X. Biomimetic ApoE-Reconstituted High Density Lipoprotein Nanocarrier for Blood-Brain Barrier Penetration and Amyloid Beta-Targeting Drug Delivery. Mol. Pharm. 2016, 13, 3976-3987. [CrossRef]

125. Prathipati, P.; Zhu, J.; Dong, X. Development of novel HDL-mimicking $\alpha$-tocopherol-coated nanoparticles to encapsulate nerve growth factor and evaluation of biodistribution. Eur. J. Pharm. Biopharm. 2016, 108, 126-135. [CrossRef] 
126. Zhu, J.; Dong, X. Preparation and characterization of novel hdl-mimicking nanoparticles for nerve growth factor encapsulation. J. Vis. Exp. 2017, e55584. [CrossRef] [PubMed]

127. Rajora, M.; Ding, L.; Valic, M.; Jiang, W.; Overchuk, M.; Chen, J.; Zheng, G. Tailored theranostic apolipoprotein E3 porphyrin-lipid nanoparticles target glioblastoma. Chem. Sci. 2017, 8, 5371-5384. [CrossRef] [PubMed]

128. Thomas, F.C.; Taskar, K.; Rudraraju, V.; Goda, S.; Thorsheim, H.R.; Gaasch, J.A.; Mittapalli, R.K.; Palmieri, D.; Steeg, P.S.; Lockman, P.R. Uptake of ANG1005, a novel paclitaxel derivative, through the blood-brain barrier into brain and experimental brain metastases of breast cancer. Pharm. Res. 2009, 26, 2486-2494. [CrossRef] [PubMed]

129. Li, Y.; Zheng, X.; Gong, M.; Zhang, J. Delivery of a peptide-drug conjugate targeting the blood brain barrier improved the efficacy of paclitaxel against glioma. Oncotarget 2016, 7, 79401. [CrossRef]

130. Haqqani, A.S.; Delaney, C.E.; Tremblay, T.-L.; Sodja, C.; Sandhu, J.K.; Stanimirovic, D.B. Method for isolation and molecular characterization of extracellular microvesicles released from brain endothelial cells. Fluids Barriers CNS 2013, 10, 4. [CrossRef]

131. Ha, D.; Yang, N.; Nadithe, V. Exosomes as therapeutic drug carriers and delivery vehicles across biological membranes: Current perspectives and future challenges. Acta Pharm. Sin. B 2016, 6, 287-296. [CrossRef]

132. Yang, T.; Fogarty, B.; LaForge, B.; Aziz, S.; Pham, T.; Lai, L.; Bai, S. Delivery of small interfering RNA to inhibit vascular endothelial growth factor in zebrafish using natural brain endothelia cell-secreted exosome nanovesicles for the treatment of brain cancer. AAPS J. 2017, 19, 475-486. [CrossRef]

133. Cai, Z.; Lei, X.; Lin, Z.; Zhao, J.; Wu, F.; Yang, Z.; Pu, J.; Liu, Z. Preparation and evaluation of sustained-release solid dispersions co-loading gastrodin with borneol as an oral brain-targeting enhancer. Acta Pharm. Sin. B 2014, 4, 86-93. [CrossRef]

134. Renú, A.; Laredo, C.; Lopez-Rueda, A.; Llull, L.; Tudela, R.; San-Roman, L.; Urra, X.; Blasco, J.; Macho, J.; Oleaga, L. Vessel Wall enhancement and blood-cerebrospinal fluid barrier disruption after mechanical thrombectomy in acute ischemic stroke. Stroke 2017, 48, 651-657. [CrossRef]

135. Wong, S.M.; Jansen, J.F.; Zhang, C.E.; Staals, J.; Hofman, P.A.; van Oostenbrugge, R.J.; Jeukens, C.R.; Backes, W.H. Measuring subtle leakage of the blood-brain barrier in cerebrovascular disease with DCE-MRI: Test-retest reproducibility and its influencing factors. J. Magn. Reson. Imaging 2017, 46, 159-166. [CrossRef] [PubMed]

136. Villringer, K.; Cuesta, B.E.S.; Ostwaldt, A.-C.; Grittner, U.; Brunecker, P.; Khalil, A.A.; Schindler, K.; Eisenblätter, O.; Audebert, H.; Fiebach, J.B. DCE-MRI blood-brain barrier assessment in acute ischemic stroke. Neurology 2017, 88, 433-440. [CrossRef]

137. Sandoval, K.E.; Witt, K.A. Blood-brain barrier tight junction permeability and ischemic stroke. Neurobiol. Dis. 2008, 32, 200-219. [CrossRef]

138. Zhang, Y.; Fan, F.; Zeng, G.; Zhou, L.; Zhang, Y.; Zhang, J.; Jiao, H.; Zhang, T.; Su, D.; Yang, C. Temporal analysis of blood-brain barrier disruption and cerebrospinal fluid matrix metalloproteinases in rhesus monkeys subjected to transient ischemic stroke. J. Cereb. Blood Flow Metab. 2017, 37, 2963-2974. [CrossRef]

139. Zhang, J.; Liu, H.; Du, X.; Guo, Y.; Chen, X.; Wang, S.; Fang, J.; Cao, P.; Zhang, B.; Liu, Z. Increasing of blood-brain tumor barrier permeability through transcellular and paracellular pathways by microbubble-enhanced diagnostic ultrasound in a c6 glioma model. Front. Neurosci. 2017, 11, 86. [CrossRef] [PubMed]

140. Karki, K.; Ewing, J.R.; Ali, M.M. Targeting glioma with a dual mode optical and paramagnetic nanoprobe across the blood-brain tumor barrier. J. Nanomed. Nanotechnol. 2016, 7, 395. [CrossRef] [PubMed]

141. Warren, M.S.; Zerangue, N.; Woodford, K.; Roberts, L.M.; Tate, E.H.; Feng, B.; Li, C.; Feuerstein, T.J.; Gibbs, J.; Smith, B. Comparative gene expression profiles of ABC transporters in brain microvessel endothelial cells and brain in five species including human. Pharmacol. Res. 2009, 59, 404-413. [CrossRef] [PubMed]

142. Sarin, H. Recent progress towards development of effective systemic chemotherapy for the treatment of malignant brain tumors. J. Transl. Med. 2009, 7, 77. [CrossRef]

143. Mäger, I.; Meyer, A.H.; Li, J.; Lenter, M.; Hildebrandt, T.; Leparc, G.; Wood, M.J. Targeting blood-brain-barrier transcytosis-perspectives for drug delivery. Neuropharmacology 2017, 120, 4-7. [CrossRef]

144. Alexis, F.; Pridgen, E.; Molnar, L.K.; Farokhzad, O.C. Factors affecting the clearance and biodistribution of polymeric nanoparticles. Mol. Pharm. 2008, 5, 505-515. [CrossRef]

145. Nel, A.; Xia, T.; Mädler, L.; Li, N. Toxic potential of materials at the nanolevel. Science 2006, 311, 622-627. [CrossRef] 
146. Pisanic, T.R., II.; Blackwell, J.D.; Shubayev, V.I.; Finones, R.R.; Jin, S. Nanotoxicity of iron oxide nanoparticle internalization in growing neurons. Biomaterials 2007, 28, 2572-2581. [CrossRef] [PubMed]

147. Kircher, M.F.; Mahmood, U.; King, R.S.; Weissleder, R.; Josephson, L. A multimodal nanoparticle for preoperative magnetic resonance imaging and intraoperative optical brain tumor delineation. Cancer Res. 2003, 63, 8122-8125. [PubMed]

148. Kim, Y.S.; Kim, J.S.; Cho, H.S.; Rha, D.S.; Kim, J.M.; Park, J.D.; Choi, B.S.; Lim, R.; Chang, H.K.; Chung, Y.H. Twenty-eight-day oral toxicity, genotoxicity, and gender-related tissue distribution of silver nanoparticles in Sprague-Dawley rats. Inhal. Toxicol. 2008, 20,575-583. [CrossRef] [PubMed]

149. Englert, C.; Brendel, J.C.; Majdanski, T.C.; Yildirim, T.; Schubert, S.; Gottschaldt, M.; Windhab, N.; Schubert, U.S. Pharmapolymers in the 21st century: Synthetic polymers in drug delivery applications. Prog. Polym. Sci. 2018, 87, 107-164. [CrossRef]

150. Verma, R.K.; Garg, S. Drug delivery technologies and future directions. Pharm. Technol. 2001, 25, 1-14.

151. Ul-Islam, S.; Ahmed, M.B.; Shehzad, A.; Ul-Islam, M.; Lee, Y.S. Failure of Chemotherapy in Hepatocellular Carcinoma Due to Impaired and Dysregulated Primary Liver Drug Metabolizing Enzymes and Drug Transport Proteins: What to Do? Curr. Drug Metab. 2018, 19, 819-829. [CrossRef]

152. Verma, P.; Thakur, A.; Deshmukh, K.; Jha, A.; Verma, S. Routes of drug administration. Int. J. Pharm. Stud. Res. 2010, 1, 54-59.

153. Djupesland, P.G. Nasal drug delivery devices: Characteristics and performance in a clinical perspective-A review. Drug Deliv. Transl. Res. 2013, 3, 42-62. [CrossRef]

154. Pardridge, W.M. Drug transport across the blood-brain barrier. J. Cereb. Blood Flow Metab. 2012, 32, $1959-1972$. [CrossRef]

155. Craft, S.; Baker, L.D.; Montine, T.J.; Minoshima, S.; Watson, G.S.; Claxton, A.; Arbuckle, M.; Callaghan, M.; Tsai, E.; Plymate, S.R. Intranasal insulin therapy for Alzheimer disease and amnestic mild cognitive impairment: A pilot clinical trial. Arch. Neurol. 2012, 69, 29-38. [CrossRef] [PubMed]

156. Godfrey, L.; Iannitelli, A.; Garrett, N.L.; Moger, J.; Imbert, I.; King, T.; Porreca, F.; Soundararajan, R.; Lalatsa, A.; Schätzlein, A.G. Nanoparticulate peptide delivery exclusively to the brain produces tolerance free analgesia. J. Control. Release 2018, 270, 135-144. [CrossRef] [PubMed]

157. Thorne, R.; Hanson, L.; Ross, T.; Tung, D.; Frey Ii, W. Delivery of interferon- $\beta$ to the monkey nervous system following intranasal administration. Neuroscience 2008, 152, 785-797. [CrossRef] [PubMed]

158. Born, J.; Lange, T.; Kern, W.; McGregor, G.P.; Bickel, U.; Fehm, H.L. Sniffing neuropeptides: A transnasal approach to the human brain. Nat. Neurosci. 2002, 5, 514. [CrossRef] [PubMed]

159. Parker, K.J.; Oztan, O.; Libove, R.A.; Sumiyoshi, R.D.; Jackson, L.P.; Karhson, D.S.; Summers, J.E.; Hinman, K.E.; Motonaga, K.S.; Phillips, J.M. Intranasal oxytocin treatment for social deficits and biomarkers of response in children with autism. Proc. Natl. Acad. Sci. USA 2017, 114, 8119-8124. [CrossRef]

160. Sigurdsson, P.; Thorvaldsson, T.; Gizurarson, S.; Gunnarsson, E. Olfactory absorption of insulin to the brain. Drug Deliv. 1997, 4, 195-200. [CrossRef]

161. Herculano-Houzel, S.; Ribeiro, P.; Campos, L.; Da Silva, A.V.; Torres, L.B.; Catania, K.C.; Kaas, J.H. Updated neuronal scaling rules for the brains of Glires (rodents/lagomorphs). Brain Behav. Evol. 2011, 78, 302-314. [CrossRef]

162. Tanaka, A.; Furubayashi, T.; Arai, M.; Inoue, D.; Kimura, S.; Kiriyama, A.; Kusamori, K.; Katsumi, H.; Yutani, R.; Sakane, T. Delivery of oxytocin to the brain for the treatment of autism spectrum disorder by nasal application. Mol. Pharm. 2018, 15, 1105-1111. [CrossRef]

163. Wang, Q.; Zhang, Y.; Wong, C.-H.; Chan, H.E.; Zuo, Z. Demonstration of direct nose-to-brain transport of unbound HIV-1 replication inhibitor DB213 via intranasal administration by pharmacokinetic modeling. AAPS J. 2018, 20, 23. [CrossRef]

164. Siew, A.; Le, H.; Thiovolet, M.; Gellert, P.; Schatzlein, A.; Uchegbu, I. Enhanced oral absorption of hydrophobic and hydrophilic drugs using quaternary ammonium palmitoyl glycol chitosan nanoparticles. Mol. Pharm. 2011, 9, 14-28. [CrossRef]

165. Buchthal, B.; Weiss, U.; Bading, H. Post-injury Nose-to-Brain Delivery of Activin A and SerpinB2 Reduces Brain Damage in a Mouse Stroke Model. Mol. Ther. 2018, 26, 2357-2365. [CrossRef] [PubMed]

166. Kamei, N.; Okada, N.; Ikeda, T.; Choi, H.; Fujiwara, Y.; Okumura, H.; Takeda-Morishita, M. Effective nose-to-brain delivery of exendin- 4 via coadministration with cell-penetrating peptides for improving progressive cognitive dysfunction. Sci. Rep. 2018, 8, 17641. [CrossRef] 
167. Shingaki, T.; Inoue, D.; Furubayashi, T.; Sakane, T.; Katsumi, H.; Yamamoto, A.; Yamashita, S. Transnasal delivery of methotrexate to brain tumors in rats: A new strategy for brain tumor chemotherapy. Mol. Pharm. 2010, 7, 1561-1568. [CrossRef] [PubMed]

168. Ahmad, E.; Feng, Y.; Qi, J.; Fan, W.; Ma, Y.; He, H.; Xia, F.; Dong, X.; Zhao, W.; Lu, Y. Evidence of nose-to-brain delivery of nanoemulsions: Cargoes but not vehicles. Nanoscale 2017, 9, 1174-1183. [CrossRef] [PubMed]

169. Patel, Z.; Patel, B.; Patel, S.; Pardeshi, C. Nose to Brain Targeted Drug Delivery bypassing the Blood-Brain Barrier: An overview. Drug Invent. Today 2012, 4, 610-615.

170. Kreuter, J. Nanoparticulate systems for brain delivery of drugs. Adv. Drug Deliv. Rev. 2001, 47, 65-81. [CrossRef]

171. Mohamed, F.; van der Walle, C.F. Engineering biodegradable polyester particles with specific drug targeting and drug release properties. J. Pharm. Sci. 2008, 97, 71-87. [CrossRef]

172. Csaba, N.; Garcia-Fuentes, M.; Alonso, M.J. The performance of nanocarriers for transmucosal drug delivery. Expert Opin. Drug Deliv. 2006, 3, 463-478. [CrossRef]

173. Yadav, N.; Khatak, S.; Sara, U.S. Solid lipid nanoparticles-a review. Int. J. Appl. Pharm. 2013, 5, 8-18.

174. Martinho, N.; Damgé, C.; Reis, C.P. Recent advances in drug delivery systems. J. Biomater. Nanobiotechnol. 2011, 2, 510. [CrossRef]

175. Thiagarajan, P. Nanoemulsions for drug delivery through different routes. Res. Biotechnol. 2011, 2, 1-13.

176. Jayaraj, R.; Chandramohan, V.; Namasivayam, E. Nanomedicine for Parkinson disease: Current status and future perspective. Int. J. Pharm. Bio. Sci 2013, 4, 692.

177. Uchegbu, I.; Wang, Z.; Xiong, G.; Tsang, A.; Schatzlein, A. Nose to brain delivery. J. Pharmacol. Exp. Ther. 2019, 370, 593-601.

178. Shah, B.; Khunt, D.; Misra, M.; Padh, H. Formulation and in-vivo pharmacokinetic consideration of intranasal microemulsion and mucoadhesive microemulsion of rivastigmine for brain targeting. Pharm. Res. 2018, 35, 8. [CrossRef] [PubMed]

179. Shah, B.; Khunt, D.; Misra, M.; Padh, H. Application of Box-Behnken design for optimization and development of quetiapine fumarate loaded chitosan nanoparticles for brain delivery via intranasal route. Int. J. Biol. Macromol. 2016, 89, 206-218. [CrossRef] [PubMed]

180. Eskandari, S.; Varshosaz, J.; Minaiyan, M.; Tabbakhian, M. Brain delivery of valproic acid via intranasal administration of nanostructured lipid carriers: In vivo pharmacodynamic studies using rat electroshock model. Int. J. Nanomed. 2011, 6, 363.

181. Van Woensel, M.; Mathivet, T.; Wauthoz, N.; Rosière, R.; Garg, A.D.; Agostinis, P.; Mathieu, V.; Kiss, R.; Lefranc, F.; Boon, L. Sensitization of glioblastoma tumor micro-environment to chemo-and immunotherapy by Galectin-1 intranasal knock-down strategy. Sci. Rep. 2017, 7, 1217. [CrossRef]

182. Seju, U.; Kumar, A.; Sawant, K. Development and evaluation of olanzapine-loaded PLGA nanoparticles for nose-to-brain delivery: In vitro and in vivo studies. Acta Biomater. 2011, 7, 4169-4176. [CrossRef]

183. Karasulu, H.Y. Microemulsions as novel drug carriers: The formation, stability, applications and toxicity. Expert Opin. Drug Deliv. 2008, 5, 119-135. [CrossRef]

184. Solans, C.; Izquierdo, P.; Nolla, J.; Azemar, N.; Garcia-Celma, M.J. Nano-emulsions. Curr. Opin. Colloid Interface Sci. 2005, 10, 102-110. [CrossRef]

185. Espinoza, L.C.; Vacacela, M.; Clares, B.; Garcia, M.L.; Fabrega, M.-J.; Calpena, A.C. Development of a Nasal Donepezil-loaded Microemulsion for the Treatment of Alzheimer's Disease: In vitro and ex vivo Characterization. CNS Neurol Disord Drug Targets. 2018, 17, 43-53. [CrossRef] [PubMed]

186. Kumar, M.; Misra, A.; Mishra, A.; Mishra, P.; Pathak, K. Mucoadhesive nanoemulsion-based intranasal drug delivery system of olanzapine for brain targeting. J. Drug Target. 2008, 16, 806-814. [CrossRef]

187. Zhang, Q.; Jiang, X.; Jiang, W.; Lu, W.; Su, L.; Shi, Z. Preparation of nimodipine-loaded microemulsion for intranasal delivery and evaluation on the targeting efficiency to the brain. Int. J. Pharm. 2004, 275, 85-96. [CrossRef] [PubMed]

188. Vyas, T.K.; Babbar, A.; Sharma, R.; Singh, S.; Misra, A. Preliminary brain-targeting studies on intranasal mucoadhesive microemulsions of sumatriptan. AAPS Pharmscitech 2006, 7, E49-E57. [CrossRef] [PubMed]

189. Vyas, T.K.; Babbar, A.; Sharma, R.; Singh, S.; Misra, A. Intranasal mucoadhesive microemulsions of clonazepam: Preliminary studies on brain targeting. J. Pharm. Sci. 2006, 95, 570-580. [CrossRef]

190. Kumar, M.; Misra, A.; Babbar, A.; Mishra, A.; Mishra, P.; Pathak, K. Intranasal nanoemulsion based brain targeting drug delivery system of risperidone. Int. J. Pharm. 2008, 358, 285-291. [CrossRef] 
191. Vyas, T.K.; Babbar, A.; Sharma, R.; Misra, A. Intranasal mucoadhesive microemulsions of zolmitriptan: Preliminary studies on brain-targeting. J. Drug Target. 2005, 13, 317-324. [CrossRef]

192. Müller, R.H.; Mäder, K.; Gohla, S. Solid lipid nanoparticles (SLN) for controlled drug delivery-a review of the state of the art. Eur. J. Pharm. Biopharm. 2000, 50, 161-177. [CrossRef]

193. Mistry, A.; Stolnik, S.; Illum, L. Nanoparticles for direct nose-to-brain delivery of drugs. Int. J. Pharm. 2009, 379, 146-157. [CrossRef]

194. Vllasaliu, D.; Exposito-Harris, R.; Heras, A.; Casettari, L.; Garnett, M.; Illum, L.; Stolnik, S. Tight junction modulation by chitosan nanoparticles: Comparison with chitosan solution. Int. J. Pharm. 2010, 400, 183-193. [CrossRef]

195. Raj, R.; Wairkar, S.; Sridhar, V.; Gaud, R. Pramipexole dihydrochloride loaded chitosan nanoparticles for nose to brain delivery: Development, characterization and in vivo anti-Parkinson activity. Int. J. Biol. Macromol. 2018, 109, 27-35. [CrossRef] [PubMed]

196. Sanchez-Ramos, J.; Song, S.; Kong, X.; Foroutan, P.; Martinez, G.; Dominguez-Viqueria, W.; Mohapatra, S.; Mohapatra, S.; Haraszti, R.A.; Khvorova, A. Chitosan-Mangafodipir nanoparticles designed for intranasal delivery of siRNA and DNA to brain. J. Drug Deliv. Sci. Technol. 2018, 43, 453-460. [CrossRef] [PubMed]

197. Carlos, M.I.S.; Zheng, K.; Garrett, N.; Arifin, N.; Workman, D.G.; Kubajewska, I.; Halwani, A.A.; Moger, J.; Zhang, Q.; Schätzlein, A.G. Limiting the level of tertiary amines on polyamines leads to biocompatible nucleic acid vectors. Int. J. Pharm. 2017, 526, 106-124. [CrossRef] [PubMed]

198. Uchegbu, I.F.; Jones, M.-C.; Corrente, F.; Godfrey, L.; Laghezza, D.; Carafa, M.; Holm, P.; Schatzlein, A.G. The oral and intranasal delivery of propofol using chitosan amphiphile nanoparticles. Pharm. Nanotechnol. 2014, 2, 65-74. [CrossRef]

199. Garrett, N.L.; Lalatsa, A.; Uchegbu, I.; Schätzlein, A.; Moger, J. Exploring uptake mechanisms of oral nanomedicines using multimodal nonlinear optical microscopy. J. Biophotonics 2012, 5, 458-468. [CrossRef] [PubMed]

200. Serrano, D.R.; Lalatsa, A.; Dea-Ayuela, M.A.; Bilbao-Ramos, P.E.; Garrett, N.L.; Moger, J.; Guarro, J.; Capilla, J.; Ballesteros, M.P.; Schätzlein, A.G. Oral particle uptake and organ targeting drives the activity of amphotericin B nanoparticles. Mol. Pharm. 2015, 12, 420-431. [CrossRef]

201. Abdou, E.M.; Kandil, S.M.; El Miniawy, H.M. Brain targeting efficiency of antimigrain drug loaded mucoadhesive intranasal nanoemulsion. Int. J. Pharm. 2017, 529, 667-677. [CrossRef]

202. Trotta, V.; Pavan, B.; Ferraro, L.; Beggiato, S.; Traini, D.; Des Reis, L.G.; Scalia, S.; Dalpiaz, A. Brain targeting of resveratrol by nasal administration of chitosan-coated lipid microparticles. Eur. J. Pharm. Biopharm. 2018, 127, 250-259. [CrossRef]

203. Danhier, F.; Ansorena, E.; Silva, J.M.; Coco, R.; Le Breton, A.; Préat, V. PLGA-based nanoparticles: An overview of biomedical applications. J. Control. Release 2012, 161, 505-522. [CrossRef]

204. Musumeci, T.; Serapide, M.F.; Pellitteri, R.; Dalpiaz, A.; Ferraro, L.; Dal Magro, R.; Bonaccorso, A.; Carbone, C.; Veiga, F.; Sancini, G. Oxcarbazepine free or loaded PLGA nanoparticles as effective intranasal approach to control epileptic seizures in rodents. Eur. J. Pharm. Biopharm. 2018, 133, 309-320. [CrossRef]

205. Zhang, C.; Chen, J.; Feng, C.; Shao, X.; Liu, Q.; Zhang, Q.; Pang, Z.; Jiang, X. Intranasal nanoparticles of basic fibroblast growth factor for brain delivery to treat Alzheimer's disease. Int. J. Pharm. 2014, 461, 192-202. [CrossRef] [PubMed]

206. Bonaccorso, A.; Musumeci, T.; Serapide, M.; Pellitteri, R.; Uchegbu, I.; Puglisi, G. Nose to brain delivery in rats: Effect of surface charge of rhodamine B labeled nanocarriers on brain subregion localization. Colloids Surf. B Biointerfaces 2017, 154, 297-306. [CrossRef]

207. Meng, Q.; Wang, A.; Hua, H.; Jiang, Y.; Wang, Y.; Mu, H.; Wu, Z.; Sun, K. Intranasal delivery of Huperzine A to the brain using lactoferrin-conjugated $\mathrm{N}$-trimethylated chitosan surface-modified PLGA nanoparticles for treatment of Alzheimer's disease. Int. J. Nanomed. 2018, 13, 705. [CrossRef]

208. Illum, L. Nasal drug delivery: New developments and strategies. Drug Discov. Today 2002, 7, 1184-1189. [CrossRef]

209. Vyas, T.K.; Shahiwala, A.; Marathe, S.; Misra, A. Intranasal drug delivery for brain targeting. Curr. Drug Deliv. 2005, 2, 165-175. [CrossRef] [PubMed]

210. Talegaonkar, S.; Mishra, P. Intranasal delivery: An approach to bypass the blood brain barrier. Indian J. Pharmacol. 2004, 36, 140. 
211. Agrawal, M.; Saraf, S.; Saraf, S.; Antimisiaris, S.G.; Chougule, M.B.; Shoyele, S.A.; Alexander, A. Nose-to-brain drug delivery: An update on clinical challenges and progress towards approval of anti-Alzheimer drugs. J. Control. Release 2018, 281, 139-177. [CrossRef]

212. Illum, L. Transport of drugs from the nasal cavity to the central nervous system. Eur. J. Pharm. Sci. 2000, 11, 1-18. [CrossRef]

213. Alexander, A.; Dwivedi, S.; Giri, T.K.; Saraf, S.; Saraf, S.; Tripathi, D.K. Approaches for breaking the barriers of drug permeation through transdermal drug delivery. J. Control. Release 2012, 164, 26-40. [CrossRef]

214. Lockman, P.; Mumper, R.; Khan, M.; Allen, D. Nanoparticle technology for drug delivery across the blood-brain barrier. Drug Dev. Ind. Pharm. 2002, 28, 1-13. [CrossRef]

215. Ugwoke, M.I.; Verbeke, N.; Kinget, R. The biopharmaceutical aspects of nasal mucoadhesive drug delivery. J. Pharm. Pharmacol. 2001, 53, 3-22. [CrossRef] [PubMed]

216. Dhuria, S.V.; Hanson, L.R.; Frey, W.H., II. Intranasal delivery to the central nervous system: Mechanisms and experimental considerations. J. Pharm. Sci. 2010, 99, 1654-1673. [CrossRef] [PubMed]

217. Pires, P.C.; Santos, A.O. Nanosystems in nose-to-brain drug delivery: A review of non-clinical brain targeting studies. J. Control. Release 2018, 270, 89-100. [CrossRef] [PubMed]

218. Crowe, T.P.; Greenlee, M.H.W.; Kanthasamy, A.G.; Hsu, W.H. Mechanism of intranasal drug delivery directly to the brain. Life Sci. 2018, 195, 44-52. [CrossRef] [PubMed]

219. Scheibe, M.; Bethge, C.; Witt, M.; Hummel, T. Intranasal administration of drugs. Arch. Otolaryngol. Head Neck Surg. 2008, 134, 643-646. [CrossRef] [PubMed]

220. Djupesland, P.G.; Skretting, A.; Winderen, M.; Holand, T. Breath actuated device improves delivery to target sites beyond the nasal valve. Laryngoscope 2006, 116, 466-472. [CrossRef]

221. Reger, M.A.; Watson, G.; Green, P.S.; Baker, L.D.; Cholerton, B.; Fishel, M.A.; Plymate, S.R.; Cherrier, M.M.; Schellenberg, G.D.; Frey, I. Intranasal insulin administration dose-dependently modulates verbal memory and plasma amyloid- $\beta$ in memory-impaired older adults. J. Alzheimer's Dis. 2008, 13, 323-331. [CrossRef]

222. Van Den Berg, M.P.; Merkus, P.; Romeijn, S.G.; Verhoef, J.C.; Merkus, F.W. Hydroxocobalamin uptake into the cerebrospinal fluid after nasal and intravenous delivery in rats and humans. J. Drug Target. 2003, 11, 325-331. [CrossRef]

223. Al-Ghananeem, A.M.; Traboulsi, A.A.; Dittert, L.W.; Hussain, A.A. Targeted brain delivery of 17 beta-estradiol via nasally administered water soluble prodrugs. AAPS Pharmscitech. 2002, 3, 40-47. [CrossRef]

224. Wong, H.L.; Wu, X.Y.; Bendayan, R. Nanotechnological advances for the delivery of CNS therapeutics. Adv. Drug Deliv. Rev. 2012, 64, 686-700. [CrossRef]

225. Putheti, R.R.; Patil, M.C.; Obire, O. Nasal Drug delivery in Pharmaceutical and biotechnology: Present and future. E-J. Sci. Technol. 2009, 4, 1-21.

(C) 2020 by the authors. Licensee MDPI, Basel, Switzerland. This article is an open access article distributed under the terms and conditions of the Creative Commons Attribution (CC BY) license (http://creativecommons.org/licenses/by/4.0/). 